\title{
Comparison of two different sea-salt aerosol schemes as implemented in air quality models applied to the Mediterranean Basin
}

\author{
P. Jiménez-Guerrero ${ }^{1}$, O. Jorba ${ }^{2}$, M. T. Pay ${ }^{2}$, J. P. Montávez ${ }^{1}$, S. Jerez ${ }^{1}$, J. J. Gómez-Navarro ${ }^{1}$, and J. M. Baldasano ${ }^{2,3}$ \\ ${ }^{1}$ Physics of the Earth, University of Murcia, Spain \\ ${ }^{2}$ Earth Sciences Department, Barcelona Supercomputing Center-Centro Nacional de Supercomputación, Barcelona, Spain \\ ${ }^{3}$ Environmental Modeling Lab, Technical University of Catalonia, Barcelona, Spain
}

Received: 13 October 2010 - Published in Atmos. Chem. Phys. Discuss.: 21 December 2010

Revised: 9 May 2011 - Accepted: 19 May 2011 - Published: 24 May 2011

\begin{abstract}
A number of attempts have been made to incorporate sea-salt aerosol (SSA) source functions in chemistry transport models with varying results according to the complexity of the scheme considered. This contribution compares the inclusion of two different SSA algorithms in two chemistry transport models: CMAQ and CHIMERE. The main goal is to examine the differences in average SSA mass and composition and to study the seasonality of the prediction of SSA when applied to the Mediterranean area with high resolution for a reference year. Dry and wet deposition schemes are also analyzed to better understand the differences observed between both models in the target area. The applied emission algorithm in CHIMERE uses a semiempirical formulation which obtains the surface emission rate of SSA as a function of the particle size and the surface wind speed raised to the power 3.41. The emission parameterization included within CMAQ is somehow more sophisticated, since fluxes of SSA are corrected with relative humidity. In order to evaluate their strengths and weaknesses, the participating algorithms as implemented in the chemistry transport models were evaluated against AOD measurements from Aeronet and available surface measurements in Southern Europe and the Mediterranean area, showing biases around -0.002 and $-1.2 \mu \mathrm{g} \mathrm{m}^{-3}$, respectively. The results indicate that both models represent accurately the patterns and dynamics of SSA and its non-uniform behavior in the Mediterranean basin, showing a strong seasonality. The levels of SSA strongly vary across the Western and the Eastern Mediterranean, reproducing CHIMERE higher annual levels in the Aegean Sea $\left(12 \mu \mathrm{g} \mathrm{m}^{-3}\right)$ and CMAQ in the Gulf of Lion $\left(9 \mu \mathrm{g} \mathrm{m}^{-3}\right)$. The large difference found for the ra-
\end{abstract}

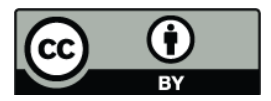

Correspondence to: P. Jiménez-Guerrero (pedro.jimenezguerrero@um.es) tio $\mathrm{PM}_{2.5} /$ total SSA in CMAQ and CHIMERE is also investigated. The dry and wet removal rates are very similar for both models despite the different schemes implemented. Dry deposition essentially follows the surface drag stress patterns, meanwhile wet deposition is more scattered over the continent. CMAQ tends to provide larger amounts of SSA dry deposition over the Northern Mediterranean (0.7$1.0 \mathrm{~g} \mathrm{~m}^{-2} \mathrm{yr}^{-1}$ ), meanwhile the Southeastern Mediterranean accounts for the maximum annual dry deposition in the CHIMERE model $\left(0.9-1.5 \mathrm{~g} \mathrm{~m}^{-2} \mathrm{yr}^{-1}\right)$. The wet deposition is dominated by the accumulation mode and is strongly correlated to the precipitation patterns, showing CMAQ a higher wet deposition/total deposition ratio over coastal mountain chains. The results of both models constitute a step towards increasing the understanding of the SSA dynamics in a complex area as the Mediterranean.

\section{Introduction}

Sea salt is the dominant aerosol mass component in the remote marine surface air and occasionally a significant one over the continents (Foltescu et al., 2005; Athanasopoulou et al., 2008). Despite a number of aerosol species is found in the atmosphere, including sulfate, black and organic carbon, mineral dust and sea salt (Haywood et al., 1999; Solmon et al., 2006; Zakey et al., 2006), on a global scale, the total mass of natural aerosols is much higher than that of anthropogenically produced types of aerosols (Lewis and Schwartz, 2004). Among them, sea-salt aerosol (SSA) is of special importance since it may have profound impacts on air quality (contributing to the high levels of particulate matter over coastal regions), ecosystems and global climate change. Global estimates of sea-salt flux are in the relatively large

Published by Copernicus Publications on behalf of the European Geosciences Union. 
range of 1000 to $10000 \mathrm{Tg} \mathrm{a}^{-1}$, which is about $30-75 \%$ of all natural aerosols. Nevertheless, fewer studies have investigated sea-salt production at the regional scale (e.g., Tindale and Pease, 1999; Vinoj and Satheesh, 2004; Foltescu et al., 2005; Athanasopoulou et al., 2008; Zakey et al., 2008, among others).

SSA is formed predominantly by the action of the wind on the ocean. The wind stress on the ocean surface forms waves, some of which break and entrain air to various depths. The bubbles rise to the surface, creating whitecaps and burst, injecting seawater drops into the atmosphere (Ma et al., 2008). A more localized mechanism of SSA production involves waves breaking in the surf zone (Athanasopoulou et al., 2008). This mechanism may affect areas even at a distance of $25 \mathrm{~km}$ from the coastline and can dominate the coastal SSA levels (Monahan, 1995; De Leeuw et al., 2000). In this sense, a number of attempts have been recently made to incorporate SSA source functions in chemistry transport models with varying results according to the complexity of the scheme considered (De Leeuw et al., 2000; Gong et al., 2002; Knipping and Dabdub, 2003; Gong, 2003; Martensson et al., 2003; Clarke et al., 2006; Kishcha et al., 2009; Kelly et al., 2010).

Albeit a large number of studies have been devoted to the climatic effects of SSA (e.g., Easter et al., 2004; Mahowald et al., 2006 and references therein) because of the SSA importance for air quality implications, we will here focus on this last topic. For air quality assessments, Manders et al. (2010) point out that it is important to resolve the large gradients in sea salt levels by using chemistry transport models. The verification of these models is severely hampered by the number of available measurements. Because of the limited number of studies, an integrated picture of SSA over the European and Mediterranean domains is not available.

Hence, this work compares the inclusion of two different SSA algorithms in two chemistry transport models: CHIMERE and CMAQ, both integrated in the CALIOPE project funded by the Spanish Ministry of the Environment (Baldasano et al., 2008; Pay et al., 2010). These models have an identical meteorological driver (WRF-ARW) and share common boundary conditions and a resolution of $12 \mathrm{~km}$. However, they differ in model formulations (different advection schemes and chemical mechanisms: Carbon Bond 4 in CMAQ and MELCHIOR2 in CHIMERE). The main goal is to examine the differences in average SSA mass and composition and to study the seasonality of the prediction of SSA when applied to the Mediterranean area with high resolution in a control year (2004). Other aspects included in the comparison are related to dry and wet deposition of SSA in the target area.

\section{Model description}

The Advanced Research Weather Research and Forecasting (WRF-ARW) Model v3.0.1.1 (Michalakes et al., 2004; Skamarock and Klemp, 2008) is used to provide the meteorology to the chemistry transport models. WRF is a fully compressible, Eulerian non-hydrostatic model that solves the equations that govern the atmospheric motions. Microphysical processes are treated using the single-moment 3-class scheme described in Hong et al. (2004). The sub-grid-scale effects of convective and shallow clouds are resolved by a modified version of the Kain-Fritsch scheme based on Kain and Fritsch $(1990,1993)$. The surface layer scheme uses stability functions from Paulson (1970); Dyer and Hicks (1970); Webb (1970) to compute surface exchange coefficients for heat, moisture, and momentum. The Noah land-surface scheme is used to provide heat and moisture fluxes over land points and sea-ice points. It is a 4-layer soil temperature and moisture model with canopy and snow cover prediction. The vertical sub-grid-scale fluxes caused by eddy transport in the atmospheric column are resolved by the Yonsei University planetary boundary layer (PBL) scheme (Noh et al., 2003). Finally, long-wave radiative processes are parameterized with the Rapid Radiative Transfer Model (Mlawer et al., 1997) while the shortwave radiative scheme is based on Dudhia (1989).

The selected chemical transport models are CHIMERE (version 2008b) and CMAQ (version 4.5). For a more complete description of the processes implemented in the models, the reader is referred to Bessagnet et al. (2004); Rouil et al. (2009) for CHIMERE and Binkowski (1999); Byun and Schere (2006) for CMAQ. Following the criteria of Jimenez et al. (2003) the Carbon Bond IV chemical mechanism (Gery et al., 1989) is applied in CMAQ, meanwhile MELCHIOR2 gas-phase mechanism is implemented within CHIMERE (Derognat et al., 2003).

Focusing on aerosol modules, CHIMERE and CMAQ share common aspects: (1) they include aerosol and heterogeneous chemistry; (2) they distinguish among different chemical aerosol components, namely nitrate, sulphate, ammonium, elemental and organic carbon with three subcomponents (primary, secondary anthropogenic and secondary biogenic) and marine aerosols. Unspecified primary anthropogenic aerosols and aerosol water are additionally kept as separate components; and (3) both models consider the thermodynamic equilibrium using the ISORROPIA model (Nenes et al., 1998).

However, important differences are found between both models. Meanwhile the aerosol microphysical description for CHIMERE is based on a sectional aerosol module including 6 bins from $10 \mathrm{~nm}$ to $40 \mu \mathrm{m}$ using a geometrical progression, in the case of CMAQ it is based on a modal aerosol model. Here, aerosols are represented by three size modes (Aitken, accumulation and coarse mode), each of them assumed to have a lognormal distribution (Binkowski 
and Roselle, 2003). As described below, the production of SSA is implemented differently in CHIMERE and CMAQ aerosol modules.

\subsection{Simulations setup}

The modeling system is initially run on a regional scale (horizontal resolution of $12 \mathrm{~km} \times 12 \mathrm{~km}$ for a domain covering Europe). Outputs are saved every hour for the entire year of simulation (2004). WRF is configured with a grid of $479 \times 399$ points and $38 \sigma$ vertical levels (11 characterizing the PBL). The model top is defined at $50 \mathrm{hPa}$ to resolve properly the troposphere-stratosphere exchanges. The simulation consists of 366 daily runs. The boundary conditions are provided at intervals of $6 \mathrm{~h}$ by the Final Analyses of the National Centers of Environmental Prediction (FNL/NCEP), being the model initialized at 12 UTC of the previous day. Hence, WRF simulations cover $36 \mathrm{~h}$ and the first $12 \mathrm{~h}$ of each meteorological run are treated as cold start, keeping the next $24 \mathrm{~h}$ for feeding the chemistry transport models CHIMERE and CMAQ. The FNL/NCEP data have a spatial resolution of $1^{\circ} \times 1^{\circ}$.

CHIMERE and CMAQ horizontal grid resolution corresponds to that of WRF; however, just the results for the Mediterranean domain are shown in this work (approx. $270 \times 110$ grid). Its vertical structure was obtained by a collapse from the $38 \mathrm{WRF}$ layers to a total of 8 and 15 layers, respectively, steadily increasing from the surface up to $100 \mathrm{hPa}$ in CHIMERE and $50 \mathrm{hPa}$ in CMAQ with a stronger density within the PBL.

Due to uncertain external influence, the definition of adequate lateral boundary conditions in a regional model is a complex issue and an important source of errors. In the present work, boundary conditions for both chemistry transport models are based on the global climate chemistry model LMDz-INCA2 $\left(96 \times 72\right.$ grid cells, namely $3.75^{\circ} \times 2.5^{\circ}$ in longitude and latitude, with $19 \sigma$-p hybrid vertical levels, Szopa et al., 2009) developed by the Laboratoire des Sciences du Climat et l'Environnement (LSCE). Monthly mean data for the year 2004 are interpolated in the horizontal and vertical dimensions to force the major chemical concentrations at the boundaries of the domain. A detailed description of the Interactive Chemistry and Aerosol (INCA) model is presented in Hauglustaine et al. (2004) and Folberth et al. (2006).

\section{Comparison of the scheme formulations for CHIMERE and CMAQ}

\subsection{Source functions}

The source for SSA function implemented within CHIMERE chemistry transport model uses the semi-empirical formulation by Monahan et al. (1986), which obtains the surface emission rate of SSA as a function only of the surface wind speed raised to the power 3.41 and particle size:

$\frac{d F}{d r}=1.373 U_{10}^{3.41} r^{-3}\left(1+0.057 r^{1.05}\right) 10^{1.19 e^{-B^{2}}}$

where $F$ is the flux of sea salt particle number, $r$ is the aerosol radius at $80 \%$ relative humidity and $U_{10}$ is the $10-\mathrm{m}$ wind speed, with $B$ :

$B=\frac{0.380-\log (r)}{0.65}$

This function is only applicable for open-ocean SSA generation. Also, this Monahan et al. (1986) scheme is valid at $80 \%$ relative humidity. To generalize it, it was modified and expressed in terms of dry radius, which is assumed to be approximatively half the radius at $80 \%$ humidity (Gerber, 1985). For further description on the implementation of this scheme within CHIMERE, the reader is referred to Bessagnet et al. (2009).

The parameterization included within CMAQ is very similar but somehow more sophisticated (for a full description see Kelly et al., 2010), since emissions of SSA are calculated as a function of wind speed and relative humidity following the parameterizations of Gong (2003) and Zhang et al. (2005). Gong (2003) modifies the distribution for large particles (diameters $>40 \mu \mathrm{m}$ at $80 \%$ relative humidity). It includes correction factors $\left(C^{0}, C^{80}\right)$ function of the relative humidity (RH) (Zhang et al., 2005, 2006a). Here, the mass distribution of SSA can be expressed as:

$$
\begin{aligned}
\frac{d F}{d r} & =C^{80} \times \mathrm{NM} \times 1.373 U^{3.41} r^{A} \times\left(1+0.057 r^{3.45}\right) \\
& \times 10^{1.609 e^{-B^{2}}}
\end{aligned}
$$

with the new terms introducing the correction by the relative humidity (Zhang et al., 2006a). The revised expression for $C^{80}$ can be used to correct the size distribution of sea-salt emissions in open oceans:

$C^{80}=1.82\left(\frac{1-\mathrm{RH}}{2.0-\mathrm{RH}}\right)^{(1 / 3)}$

Zhang et al. (2005) relate $C^{0}$ and $C^{80}$ according to the following expression:

$C^{80}=C^{0} / 1.97$

The rest of the terms can be defined as:

$\mathrm{NM}=10^{-15} \pi \frac{8 r^{3}}{6} \rho \chi$
$B=\frac{0.433-\log (r)}{0.433}$
$A=4.7(1+\Theta r)^{-0.017 r^{-1.44}}, \quad \Theta=30$

where $r$ is the radius of the particle at ambient $\mathrm{RH}, U$ is the 10-m wind speed, $F$ is the mass flux, $\rho$ is the density of the particle and $\chi$ the mass fraction of the solute. 


\subsection{Deposition schemes}

\subsubsection{Dry deposition}

Dry deposition is the mechanism by which pollutants in the form of either gases or small particles can also be transported to ground level and absorbed and/or adsorbed by material there with first being dissolved in atmosphere water droplets. The representation of dry deposition processes is still nowadays a large source for uncertainty (Manders et al., 2010). Textor et al. (2006) recognize the large differences between different global models with respect to dry deposition fluxes and efficiencies.

The dry deposition schemes in CHIMERE and CMAQ follow similar approaches. In both, dry deposition flux is directly proportional to the local concentration $C$ of the depositing species (in this case, SSA):

$F=-v_{\mathrm{d}} C$

where $F$ represents the vertical dry deposition flux, the amount of material depositing to a unit surface area per unit time. The proportionally constant between flux and concentration, $v_{\mathrm{d}}$, is known as the deposition velocity. Because $C$ is a function of height $z$ above the ground, $v_{\mathrm{d}}$ is a function of $z$ and must be related to a reference height at which $C$ is specified.

The process of dry deposition of gases and particles are similarly represented in both models as consisting of three steps: (1) aerodynamic transport down through the atmospheric surface layer to the quasilaminar sublayer; (2) molecular (for gases) or Brownian (for particles) transport across this thin stagnant layer of air, quasilaminar sublayer to the surface; (3) uptake at the surface. The main factors governing dry deposition are the grade of the atmospheric turbulence, the chemical properties of the species, and the nature of the soil and the vegetations. However, the main differences are highlighted below.

In CHIMERE, the dry deposition of aerosols makes use of a resistance scheme (Wesely, 1989). The dry deposition velocity follows the formulation of Seinfeld and Pandis (1997):

$v_{\mathrm{d}}=\frac{1}{\left(r_{\mathrm{a}}+r_{\mathrm{b}}+r_{\mathrm{a}} r_{\mathrm{b}} v_{\mathrm{s}}\right)}+v_{\mathrm{s}}$

where $r_{\mathrm{a}}$ is the aerodynamic resistance (or aerodynamic $\mathrm{drag}), r_{\mathrm{b}}$ is the resistance at the quasi laminar sublayer. The aerodynamics resistance is calculated as the integral of the inverse of the diffusivity coefficient $K_{z}$ up to the middle of the model surface layer, which can be estimated using the analytical formulae of the surface-layer similarity profiles for $K$ (Seinfeld and Pandis, 1997). $v_{\mathrm{s}}$ stands for the sedimentation velocity. Over vegetal canopies, corrections have been implemented (Giorgi, 1986; Peters and Eiden, 1992; Zhang et al., 2001).

Despite CMAQ initially included the same description for the dry deposition of aerosols, as also defined by Binkowski and Shankar (1995), the version of CMAQ implemented in this study follows a modified approach, according to Venkatram and Pleim (1999). The dry deposition is now parameterized following a non-electrical analogy. The objective for using this formulation is to be consistent with the mass conservation. Dry deposition velocity used in CMAQ is defined as follows:

$v_{\mathrm{d}}=\frac{v_{\mathrm{s}}}{\left(1-e^{-r v_{\mathrm{s}}}\right)}$

where $r$ is the sum of all the resistances. For particles, $r=r_{\mathrm{a}}+r_{\mathrm{b}}$.

\subsubsection{Wet deposition}

In CHIMERE, wet deposition fluxes are summed up in the whole column since, in the model, each vertical level may contribute to a net sink. The wet scavenging of particles is formulated as follows:

1. For particles in clouds: particles can be scavenged either by coagulation with cloud droplets or by precipitating drops. Particles also act as cloud condensation nuclei to form new droplets. This latter process of nucleation in the most efficient one in clouds. According to Guelle et al. (1998) and Tsyro (2002), the wet deposition flux in CHIMERE is written as:

$$
\left[\frac{d Q_{l}^{k}}{d t}\right]=-\frac{\epsilon_{l} p}{w_{1} h} Q_{l}^{k}
$$

where $p$ is the precipitation rate released in the grid cell $\left(\mathrm{g} \mathrm{cm}^{-2} \mathrm{~s}^{-1}\right), w_{1}$ the liquid water content $\left(\mathrm{g} \mathrm{cm}^{-3}\right), h$ the cell thickness $(\mathrm{cm})$ and $\epsilon$ an empirical uptake coefficient (in the range 0-1) depending on particle hygroscopicity. $l$ and $k$ denote the bin and composition subscripts.

2. For particles in rain droplets below the clouds: particles are scavenged by raining drops, the deposition flux of particles being:

$\left[\frac{d Q_{l}^{k}}{d t}\right]=-\frac{\alpha p E_{l}}{u_{g}} Q_{l}^{k}$

with $\alpha$ being an empirical coefficient, $p$ the precipitation rate in the grid cell $\left(\mathrm{g} \mathrm{cm}^{-2} \mathrm{~s}^{-1}\right), E$ a collision efficiency coefficient between particles and raining drops (Loosmore and Cederwall, 2004) and $u_{g}$ the falling drop velocity $\left(\mathrm{cm} \mathrm{s}^{-1}\right)$.

The description of the aerosol scavenging and wet deposition in CMAQ is taken from Byun and Schere (2006). Pollutant scavenging in CMAQ is calculated by two methods, depending on whether the pollutant participates in the cloud water chemistry. For those pollutants that are absorbed into 
the cloud water and participate in the cloud chemistry, the amount of scavenging depends on Henry's law constants, dissociation constants, and cloud water $\mathrm{pH}$. For pollutants that do not participate in aqueous chemistry, the model uses the effective Henry's law equilibrium equation to calculate ending concentrations and deposition amounts. The rate of change for in-cloud concentrations $\left(m_{i}^{\text {cld }}\right)$ for each pollutant following the cloud time scale $\tau_{\text {cld }}$ is given by:

$$
\left.\frac{\partial \overline{m_{i}^{\text {cld }}}}{\partial t}\right|_{\text {scav }}=\overline{m_{i}^{\text {cld }}}\left(\frac{e^{-\alpha_{i} \tau_{\mathrm{cld}}}-1}{\tau_{\mathrm{cld}}}\right)
$$

where $\alpha_{i}$ is the scavenging coefficient for the pollutant. For sub-grid convective clouds, $\tau_{\text {cld }}$ is $1 \mathrm{~h}$ and for grid-resolved clouds it is equal to the CMAQ's synchronization time step. The accumulation mode and coarse mode aerosols are assumed to be completely absorbed by the cloud and rain water. Therefore, the scavenging coefficients for these two aerosol modes are simply a function of the washout time $\tau_{\text {washout }}$, representing the amount of time required to remove all the water from the cloud volume at the specified precipitation rate:

$\alpha_{i}=\tau_{\text {washout }}^{-1}$

The Aitken mode aerosols are treated as interstitial aerosol and are slowly absorbed into the cloud/rain water. An assumption used is that organics influence neither the water content nor the ionic strength of the system (Kim et al., 1993).

The wet deposition algorithms in CMAQ were taken from the RADM (Chang et al., 1987). In the current implementation, deposition is accumulated over $1 \mathrm{~h}$ increments before being written to the output file. The wet deposition amount of chemical species $i$ (wdep ${ }_{i}$ ) depends on the precipitation rate $P_{\mathrm{r}}$ and the cloud water concentration $\left(m_{i}^{\text {cld }}\right)$ :

$\operatorname{wdep}_{i}=\int_{0}^{\tau_{\mathrm{cld}}} \overline{m_{i}^{\mathrm{cld}}} P_{\mathrm{r}} d t$

\section{Results}

\subsection{Meteorological model evaluation}

Despite the meteorological fields are common for both schemes, it is interesting to perform an evaluation of the WRF-ARW results for the year 2004 in order to understand the skill of the model to capture the seasonality of meteorological variables in the Mediterranean. Hence, the 2-m temperature, 2-m dew point temperature, 10-m wind speed and direction and precipitation are evaluated against surface meteorological observations. 931 meteorological stations are used to evaluate the temperature and wind variables over all the European continent and Northern Africa; however just the results for the Mediterranean domain are depicted in
Table 1. Summary of annual mean errors of the meteorological model WRF for 2-m temperature, 2-m dew point temperature, 10$\mathrm{m}$ wind speed and $10-\mathrm{m}$ wind direction.

\begin{tabular}{lrrr}
\hline & RMSE & MAE & MB \\
\hline Temperature $\left({ }^{\circ} \mathrm{C}\right)$ & 2.57 & 1.84 & -0.14 \\
Dewpoint temperature $\left({ }^{\circ} \mathrm{C}\right)$ & 2.58 & 1.84 & -0.85 \\
Wind speed $\left(\mathrm{m} \mathrm{s}^{-1}\right)$ & 2.67 & 1.99 & 1.13 \\
Wind direction $\left({ }^{\circ}\right)$ & 64.34 & 46.57 & 4.79 \\
\hline
\end{tabular}

Fig. 1. The observational datasets consist of hourly measurements from METAR, SYNOP, AWOS and ASOS networks. On the other hand, precipitation has been evaluated against 40 stations located over Spain from SYNOP network.

The quantitative evaluation is performed using classical statistics for temperature and wind, like the root mean squared error (RMSE), the mean absolute error (MAE) and the mean bias (MB) (Willmott et al., 1985). On the other hand, the Equitable Threat Score (ETS) and bias skill scores (Wilks, 1995; Ebert et al., 2003) are used to evaluate the 24-h accumulated precipitation. Thresholds of precipitation greater or equal to $0.5,2,5,10$ and $20 \mathrm{~mm}$ are used.

Table 1 shows the annual mean RMSE, MAE and MB for 2-m temperature and dew point temperature, 10-m wind speed and direction. In general, the mean absolute errors for temperature variables remain below $2^{\circ} \mathrm{C}$. A slight cold bias in temperature is produced. Also, the wind shows a rather good performance with MAE below $2 \mathrm{~m} \mathrm{~s}^{-1}$ and $46.5^{\circ}$. The model tends to overestimate the wind speed. The monthly mean evolution of the MAE and MB for these variables shows a cold bias at surface levels, observed during most parts of the year. The model tends to simulate colder and dryer atmospheres as indicated by the larger underestimation of dew point temperature compared with the sensible temperature. This bias difference between both temperatures is rather constant and the MAE remains between $1.7^{\circ} \mathrm{C}$ and $2.0^{\circ} \mathrm{C}$.

The model overestimates the surface wind speed, although the error remains below $2.5 \mathrm{~m} \mathrm{~s}^{-1}$ during wintertime and below $1.6 \mathrm{~m} \mathrm{~s}^{-1}$ in summertime. It is important to note that the direction error is quite stable, around $40^{\circ}$. These results indicate the reasonable good performance at surface level of the meteorological model over the Mediterranean for 2004.

In order to illustrate the distribution of the error spatially, Fig. 1 shows the 10-m wind speed MAE of January and July 2004 for the stations located within the domain under study (Southern Europe and Mediterranean Basin). All Mediterranean coastal stations have errors between 2.5 and $3 \mathrm{~m} \mathrm{~s}^{-1}$ in January whereas the error clearly decreases up to $1 \mathrm{~m} \mathrm{~s}^{-1}$ in July when calm to moderate winds dominate the region. From all the coastal areas, the Eastern Adriatic coast is the one where the model presents major problems to accurately 

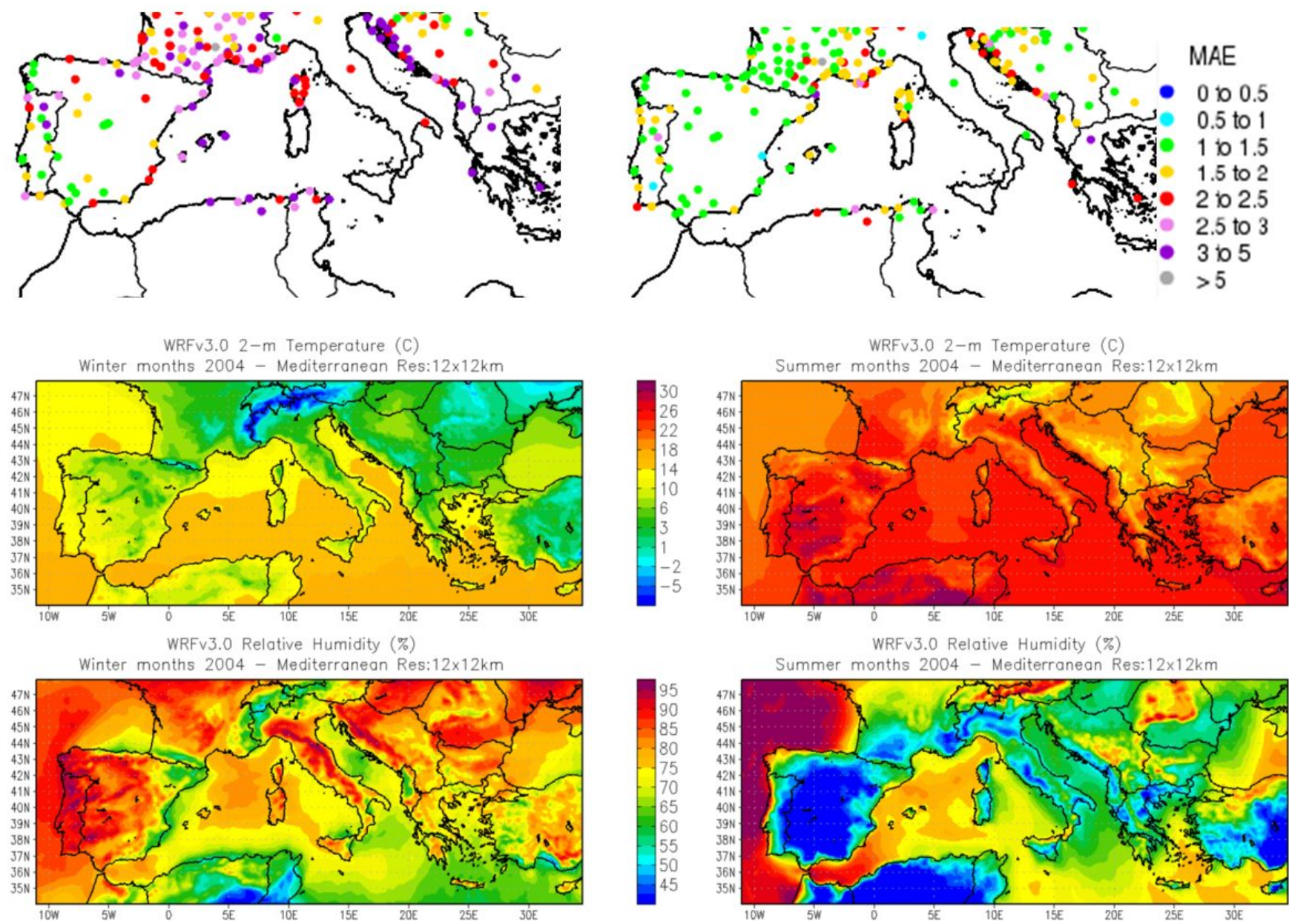

WRFv3.0 Daily Mean Precipitation ( $\mathrm{mm} /$ day)
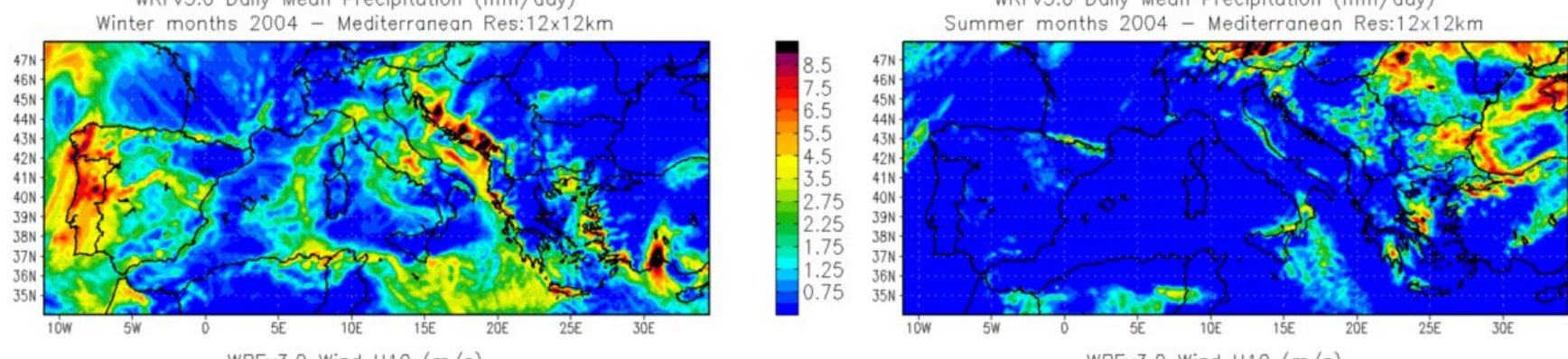

WRF 3.0 Wind $U 10(\mathrm{~m} / \mathrm{s})$
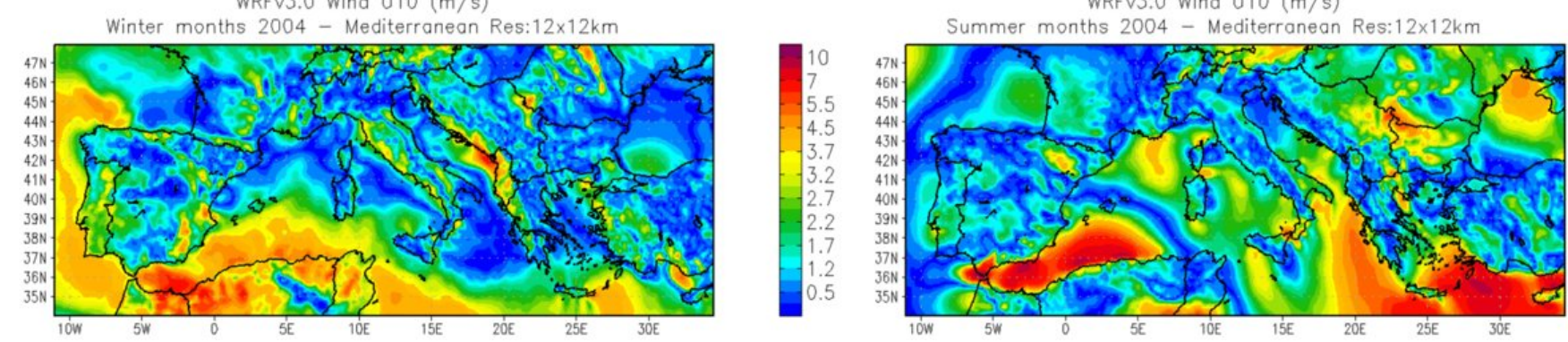

Fig. 1. (Top) map of the spatial distribution of the monthly MAE of 10-m wind speed (left) for January and (right) July 2004 (color legend in the right panel; units in $\mathrm{m} \mathrm{s}^{-1}$ ); (down) seasonal averages of modeled meteorological fields involved in SSA production: winter (left) and summer (right) 2-m temperature $\left({ }^{\circ} \mathrm{C}\right)$, relative humidity $(\%)$, precipitation $\left(\mathrm{mm} \mathrm{d}^{-1}\right)$ and wind speed $\left(\mathrm{m} \mathrm{s}^{-1}\right)$. 
reproduce the wind speed. It is not surprising, considering the complexity of this area characterized by very complex terrain. The model evaluation shows a model performance quite uniform over the entire domain.

Finally, two skills scores to evaluate the precipitation results of WRF-ARW model have been estimated. It is important to note that the skill scores have been computed comparing grid model results against observation points. This approach usually leads to lower skill scores compared with methodologies that use gridded precipitation analysis as a reference (Cherubini et al., 2002). In this case, observations were used instead of precipitation analysis due to the difficulties to obtain such kind of dataset for 2004. The ETS is above 0.3 for precipitation events with thresholds over $10 \mathrm{~mm}$ in $24 \mathrm{~h}$. The bias is over 1, indicating the trend of the model to overestimate some precipitation events not captured by the observations. A reasonable good performance is achieved, although the bias of the system is important for intense precipitation events.

\subsection{Chemistry transport model evaluation against observations (air quality networks and aerosol optical depth, AOD)}

The participating algorithms as implemented in the chemistry transport models were evaluated against Aerosol Optical Depth (AOD) measurements from Aeronet (Holben et al., 2001; Smirnov et al., 2002) for those stations with a strong influence of SSA (Forth Crete, Oristiano, Lampedusa and Messina) in order to quantify the skills of the model for reproducing the total AOD coming from both anthropogenic and natural sources. The optical depth from CHIMERE and CMAQ components was obtained as the sum of the extinction coefficient $\beta_{\mathrm{sp}}$ of each aerosol species, along the atmospheric column with layers $i$ of thickness $z_{i}$ :

$\mathrm{AOD}_{\text {model }}=\sum_{i=1}^{N} \beta_{\mathrm{sp}} \Delta z_{i}$

AOD (at $550 \mathrm{~nm}$ ) from CHIMERE and CMAQ outputs is calculated using a simple approach which takes into account the mass concentration of aerosols in each layer of the model. The method is known as the "reconstructed mass-extinction method" and described by Malm et al. (1994) and Binkowski and Roselle (2003).

The mass concentration for each species is directly obtained from CHIMERE and CMAQ. A relative humidity correction factor (Tang et al., 1981; Tang, 1996) takes into account that the growth and phase change of hygroscopic particles affect their light-scattering efficiency (Malm et al., 1994). The factor $f(\mathrm{RH})$ is parameterized from data published by Tang et al. (1981) as a function of the relative humidity, taken from the WRF-ARW meteorological model. $f(\mathrm{RH})$ varies between 1 (at low $\mathrm{RH}$ ) and 21 (at $\mathrm{RH}=99 \%$ ).

The main goal of this work is not to provide a comprehensive evaluation of the model behavior at ground level for reproducing $\mathrm{PM}_{10}$ and $\mathrm{PM}_{2.5}$ levels, but to highlight how different sea-salt schemes implemented in different CTMs intercompare when applied to the Mediterranean area. However, specific works on the evaluation of the models included in the CALIOPE system for reproducing aerosol levels over all Europe and the southwestern Mediterranean can be found in Pay et al. (2010) and Baldasano et al. (2011), respectively. Nonetheless, in this section we present an evaluation focusing on SSA for the reference year (2004). The lack of measurements of SSA at ground level during the simulation period does not allow a detailed evaluation of the model results. However, Querol et al. (2009) and Manders et al. (2010) compile the measurements of levels and composition of SSA during similar periods (from 2001 to 2008) and therefore modeling results were compared with observations as an order of magnitude test.

A number of metrics were used to examine the model performance. Correlation coefficient $(r)$ measures the model and observations change together (at the same time and/or location). Root Mean Square Error (RMSE) indicates the skill in simulating the overall magnitude of the observation. Another common metric used to quantify the departure between modeled and observed quantities is the mean bias (MB), a useful measure of the overall over- or under-estimation by the model. Relative measurements are particularly useful in comparing the performance of models. According to particulate matter evaluation, Boylan and Russell (2006) suggested to use mean fractional bias (MFB) and mean fractional error (MFE) instead. They propose that a model performance goal is met when both the MFE and MB are less than or equal to $50 \%$ and $\pm 30 \%$, respectively, and a model performance criterion is met when both MFE $\leq 75 \%$ and MFB less than or equal to $\pm 60 \%$.

Table 2 and Fig. 2 indicates a summary of the modeled SSA evaluation. The comparison of Querol et al. (2009) measurements and modeling results showed a satisfactory spatial distribution of aerosols in the area of the Mediterranean, with spatial correlation values reaching 0.806 for CHIMERE and 0.808 for CMAQ. There is a trend to underestimate the levels of aerosols (mean bias of $-1.15 \mu \mathrm{g} \mathrm{m}^{-3}$ for CHIMERE and $-0.48 \mu \mathrm{g} \mathrm{m}^{-3}$ for CMAQ), involving RMSE of 1.84 and $1.06 \mu \mathrm{g} \mathrm{m}^{-3}$, respectively. This underestimation is also calculated for the MFB, with values of $-19.63 \%$ and $-15.70 \%$ for the fractional bias and $49.74 \%$ and $48.57 \%$ for the fractional error. These values by far meet the model perfomance goal and criteria established by Boylan and Russell (2006) for an accurate behavior of air quality models when representing PM processes. These results suggest that the SSA emissions algorithms provide reasonable mass fluxes, as also indicated in Nolte et al. (2008) and Manders et al. (2010) for a similar sea-salt modeling application.

With respect to the optical depth, the models reproduce the highest AOD values in the spring season (namely the April-May period, up to 0.244 in CHIMERE and 0.222 in CMAQ) and minimum in wintertime (0.093 and 0.132 for 
Table 2. Summary of the annual statistical evaluation for AOD at $550 \mathrm{~nm}$ from the Aeronet network and SSA ground-level based observations of $\mathrm{PM}_{10}\left(\mu \mathrm{g} \mathrm{m}^{-3}\right)$ included in Querol et al. (2009)*.

\begin{tabular}{lrrrr}
\hline & \multicolumn{2}{c}{$\begin{array}{c}\text { Aeronet } \\
\text { Mean: 0.152 }\end{array}$} & \multicolumn{2}{c}{$\begin{array}{c}\text { Querol et al. (2009) } \\
\text { Mean: 2.56 } \mu \mathrm{g} \mathrm{m}^{-3}\end{array}$} \\
& CHIMERE & CMAQ & CHIMERE & CMAQ \\
\hline Annual mean & 0.140 & 0.146 & $1.41 \mu \mathrm{g} \mathrm{m}^{-3}$ & $1.89 \mu \mathrm{g} \mathrm{m}^{-3}$ \\
Root mean square error (RMSE) & 0.030 & 0.022 & $1.84 \mu \mathrm{g} \mathrm{m}^{-3}$ & $1.06 \mu \mathrm{g} \mathrm{m}^{-3}$ \\
Mean bias (MB) & -0.002 & -0.001 & $-1.15 \mu \mathrm{g} \mathrm{m}^{-3}$ & $-0.48 \mu \mathrm{g} \mathrm{m}^{-3}$ \\
Mean fractional bias (MFB) & $-4.50 \%$ & $-0.70 \%$ & $-19.63 \%$ & $-15.70 \%$ \\
Mean fractional error (MFE) & $20.36 \%$ & $18.42 \%$ & $49.74 \%$ & $48.57 \%$ \\
Correlation $(r)$ & 0.66 & 0.68 & 0.81 & 0.81 \\
\hline
\end{tabular}

* Stations: Streithofen (Austria) Puxbaum et al. (2004); Chaumont (Switzerland) Hueglin et al. (2005); Bemantes (Spain) Salvador et al. (2007); Montseny (Spain) Querol et al. (2009); Monagrega (Spain) Rodriguez et al. (2004); Villar del Arzobispo (Spain) Viana et al. (2008); Finokalia (Crete) Querol et al. (2009); Erdemlii (Turkey) Querol et al. (2009).
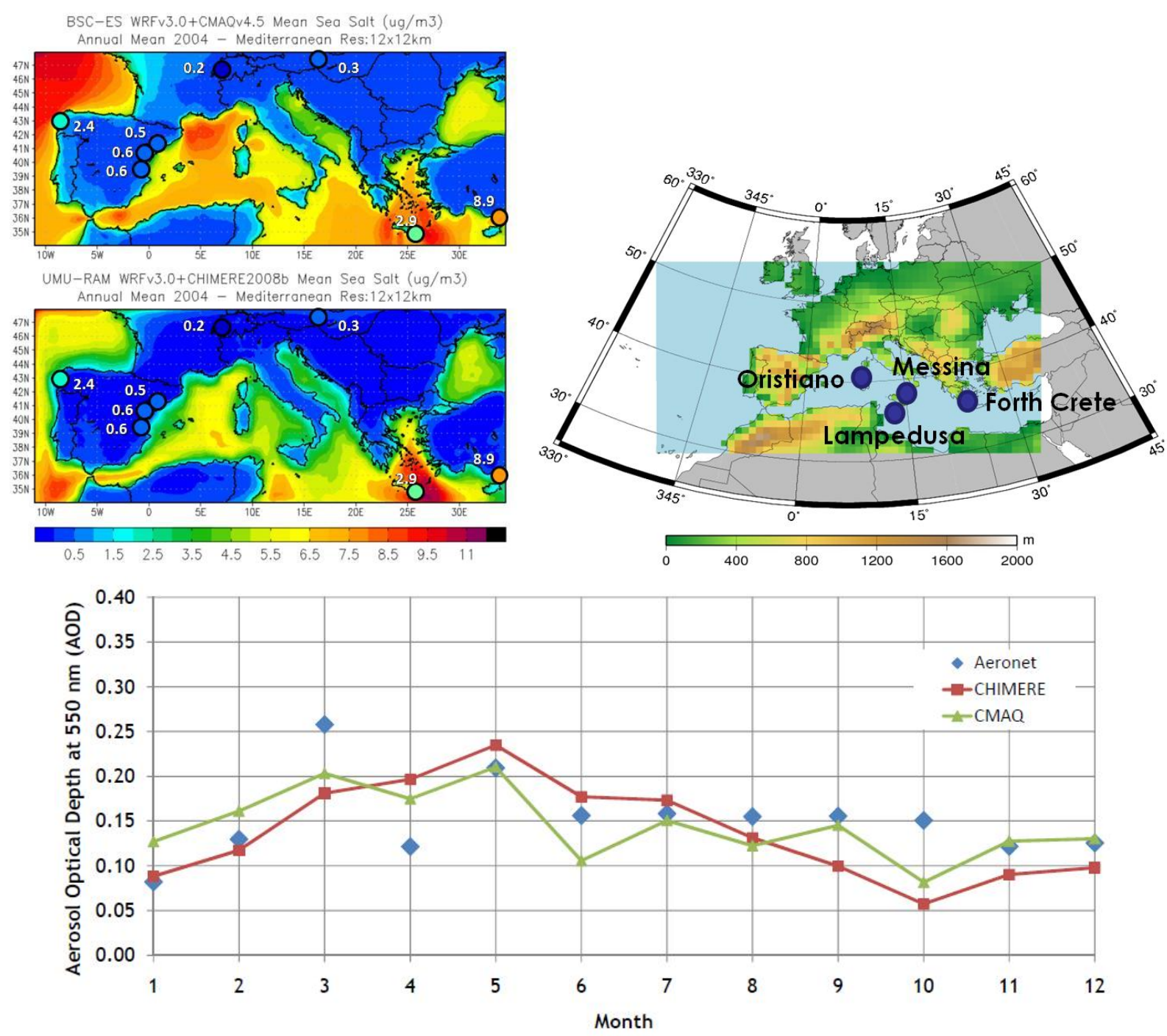

Fig. 2. Up, left) modeled annual mean SSA concentration $\left(\mu \mathrm{g} \mathrm{m}^{-3}\right)$ for WRF + CMAQ (top) and WRF+CHIMERE (bottom) simulations. Filled circles indicate the concentrations at the stations reported by Querol et al. (2009); (up, right) location of the Aeronet stations used in this work for evaluation; (down) average results of Aerosol Optical Depth for Aeronet stations (blue diamonds), CHIMERE (red line) and CMAQ (green line). The numerical results of the statistical evaluation are shown in Table 2. 
CHIMERE and CMAQ, respectively) for the stations considered (Fig. 2). However, the AOD comparisons suggest that the model underpredicts total column sea salts, with biases of $-0.002(-4.50 \%)$ and $-0.001(-0.70 \%)$ in the mean values of optical depth in the Mediterranean stations. Despite these locations were selected because they present a weak influence of anthropogenic aerosols, allowing an accurate comparison, Mahowald et al. (2006) indicate that the main source for this discrepancy is likely the contribution of additional aerosols in the observed AOD; thus the optical depths from Aeronet have been compared to the simulated values for $\mathrm{AOD}_{\text {total }}$. If we analyze the optical depths including only water surfaces, our simulated values are comparable with those of Smirnov et al. (2002), who argue that the aerosol optical thickness is less than 0.1 over most of the clean oceans, with a mean value of 0.07 . In our simulation the mean aerosol optical depth over the Mediterranean is 0.086 for CMAQ and 0.084 for CHIMERE. Note that the values obtained here are much higher than those of 0.049 obtained by Mahowald et al. (2006) in global model simulations and 0.006 reported by Zakey et al. (2008) for the Mediterranean region.

\subsection{Differences in the levels of sea-salt aerosols over the Mediterranean}

With respect to the mean and maximum 2004 concentrations (Fig. 3), it should be highlighted that the levels of SSA vary strongly across the Western and the Eastern Mediterranean, reproducing CHIMERE higher levels in the Aegean Sea $\left(12 \mu \mathrm{g} \mathrm{m}^{-3}\right)$ and CMAQ in the Gulf of Lion $\left(9 \mu \mathrm{g} \mathrm{m}^{-3}\right)$; these are the areas where the differences CMAQ-CHIMERE are largest $\left(-4 \mu \mathrm{g} \mathrm{m}^{-3}\right.$ in the Eastern Mediterranean and $+5.5 \mu \mathrm{g} \mathrm{m}^{-3}$ in the Northwestern Mediterranean). CMAQ reproduces high levels also in the Atlantic Ocean (difference CMAQ-CHIMERE $+6 \mu \mathrm{g} \mathrm{m}^{-3}$ ). This feature, reported by Visser et al. (2001) and Querol et al. (2009) by using observation data, is not well captured by CHIMERE. One should expect similar concentrations in CMAQ and CHIMERE, but the correction by the relative humidity plays an important role, especially over the Atlantic area (as stated in the Fig. 1, the relative humidity in this region exceeds $90 \%$ especially during summertime). The maximum concentration does not show a clear pattern, with the highest modeled SSA concentrations located over open ocean (Atlantic and Mediterranean, above $55 \mu \mathrm{g} \mathrm{m}^{-3}$ reproduced by CMAQ); however, large differences appear in the location of the maxima (CMAQ-CHIMERE difference of $-35 \mu \mathrm{g} \mathrm{m} \mathrm{m}^{-3}$ over the Aegean sea and $+30 \mu \mathrm{g} \mathrm{m}^{-3}$ in the Northern Mediterranean basin). Above the Atlantic, higher concentrations are reached due to higher wind speeds; furthermore, a different behaviour is observed over coastal areas, with CMAQ reproducing highest SSA concentrations, since emission fluxes in CHIMERE are highly dependent on the definition of the wind speed over sea-land interfaces and its representation within the schemes. Both models reproduce the lowest max- ima levels in the Adriatic and Tyrrhenian seas (around 15$20 \mu \mathrm{g} \mathrm{m}^{-3}$ ). According to Manders et al. (2010), the maximum concentration gradually decreases from the Western European coastline to inland locations since easterly winds do not read high speeds as westerly winds are associated with considerably shorter fetches thus causing lower sea salt emissions and loads.

The seasonal results indicate that both models represent accurately the patterns and dynamics of SSA and its non-uniform behavior in the Mediterranean Basin, showing a strong seasonality. Averaging for the entire Mediterranean region, both models indicate that the maximum concentrations are simulated during the December-January-February (DJF) period, while lower concentrations are simulated in June-July-August (JJA) (Fig. 4), being springtime and autumn transition periods. The winter maxima are related to the occurrence of intense frontal systems and strong wind events that peak during this season, especially over the coastal areas of the Western Mediterranean (Alpert and Ganor, 1993; Saaroni et al., 1998), as observed for the CMAQ simulations in the Gulf of Lion for the DJF period. Zakey et al. (2008) state that these are regions of strong Mediterranean cyclogenesis, with maximum activity taking place in the winter and autumn months (Camuffo et al., 2000; Cavaleri, 2005). For summertime, the Gong scheme implemented in CMAQ reproduces a very similar concentration of marine aerosol as Monahan et al. (1986) implemented in CHIMERE for the Western Mediterranean (Alboran Sea and Gulf of Lion) during summertime $\left(5.4 \mu \mathrm{g} \mathrm{m}^{-3}\right.$ vs. $5.6 \mu \mathrm{g} \mathrm{m}^{-3}$ as an average over the Mediterranean Sea), related to the increasing sea breeze circulation over the coast which intensifies in the mid-summer (Querol et al., 2009). On the contrary, Monahan scheme does not clearly reproduce this variation between summertime and wintertime. If we focus on the Eastern Mediterranean, no large differences are found between both schemes; here the sea spray clearly follows the wind speed variation in both models. Remote continental locations show the lowest SSA concentrations, with average seasonal values below $0.5 \mu \mathrm{g} \mathrm{m}^{-3}$.

Last, a large difference is found for the SSA in $\mathrm{PM}_{2.5}$ between CMAQ and CHIMERE (Fig. 5), since the scheme implemented in CMAQv4.5 considers coarse-mode aerosols as dry and inert. Therefore, components in the coarse mode cannot evaporate or condense. This approach does not allow important aerosol processes, such as replacement of chloride by nitrate in mixed marine/urban air masses, to be simulated (Kelly et al., 2010). Moreover, degassing of $\mathrm{Cl}^{-}$is not implemented in the model, and heterogeneous reactions are not taken into account. Transfer from $\mathrm{PM}_{10}$ to $\mathrm{PM}_{2.5}$ is also not considered in CMAQv4.5. Zhang et al. (2006b) report over-prediction of geometric mean diameter by CMAQ and Elleman and Covert (2009) also reported that CMAQ size distributions are shifted to larger sized compared with observations. This discrepancy may influence $\mathrm{PM}_{2.5}$ predictions, that will increase if over-predictions of the geometric mean 

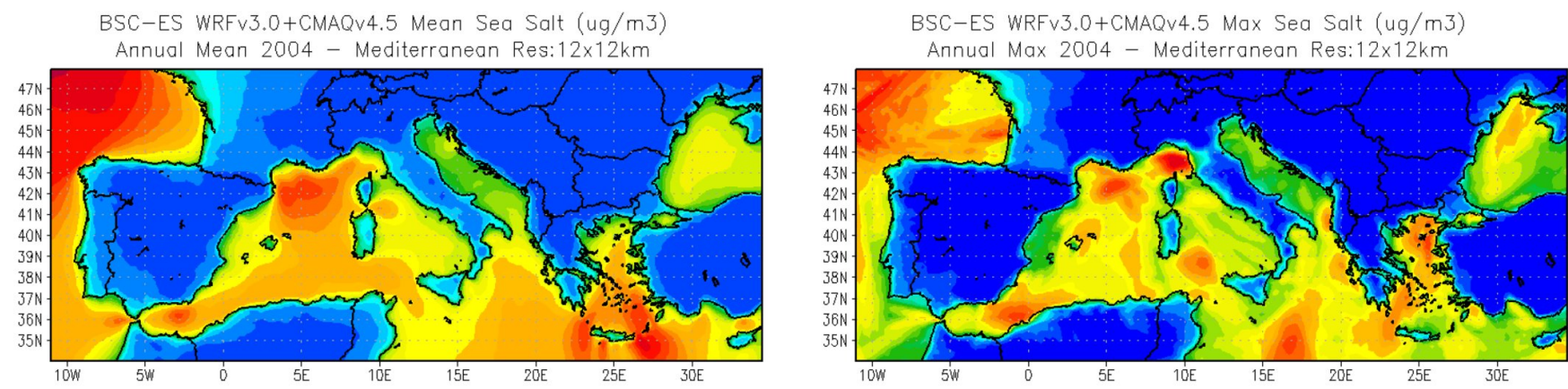

UMU-RAM WRFv3.0+CHIMERE2008b Mean Sea Salt (ug/m3) Annual Mean 2004 - Mediterranean Res:12x12km

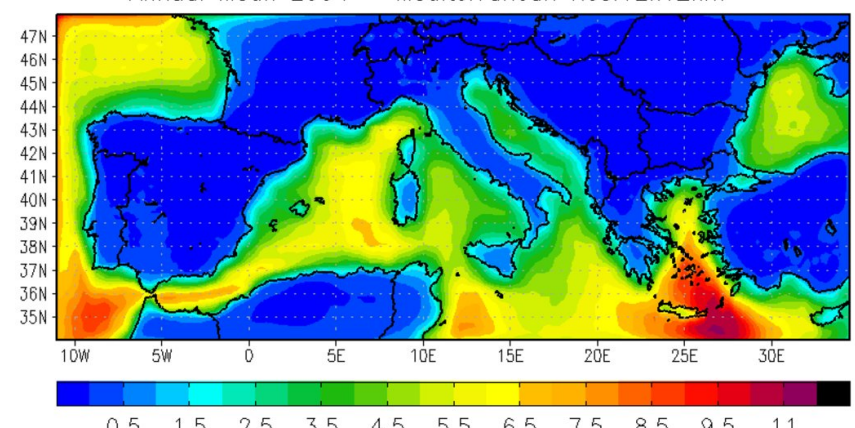

UMU-RAM WRFv3.0+CHIMERE2008b Max Sea Salt (ug/m3) Annual Max 2004 - Mediterranean Res: $12 \times 12 \mathrm{~km}$

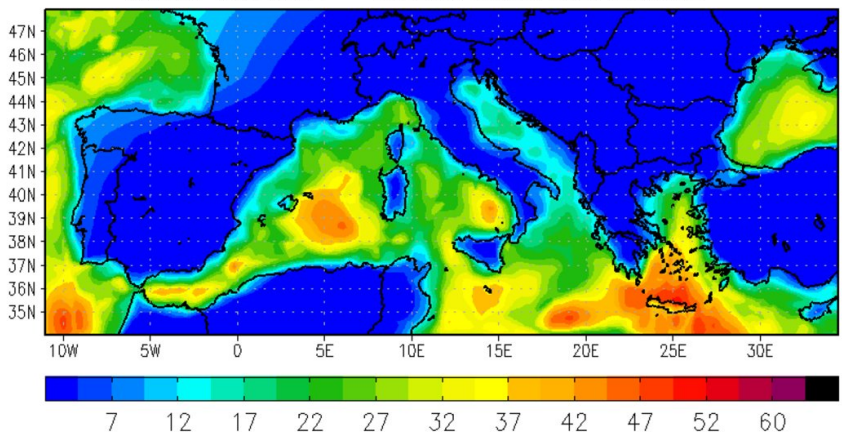

CMAQv4.5-CHIMERE2008b Max Sea Salt Difference (ug/m3) Annual Max 2004 - Mediterranean Res: $12 \times 12 \mathrm{~km}$

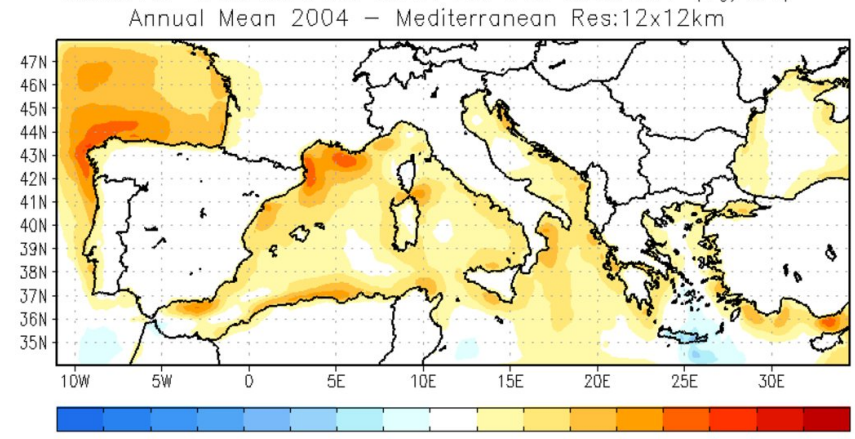

$\begin{array}{llllllllllllllll}-8 & -7 & -6 & -5 & -4 & -3 & -2 & -1 & 1 & 2 & 3 & 4 & 5 & 6 & 7 & 8\end{array}$

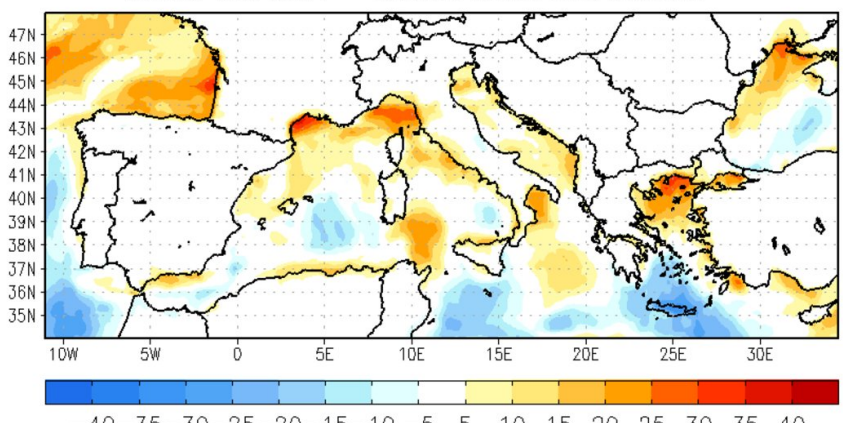

Fig. 3. (Left) modeled annual mean SSA concentration $\left(\mu \mathrm{g} \mathrm{m}^{-3}\right)$ for WRF + CMAQ (top), WRF + CHIMERE (center) and difference between CMAQv4.5-CHIMERE2008b mean SSA concentrations (bottom); (right) modeled annual maximum SSA concentration ( $\mu \mathrm{g} \mathrm{m}^{-3}$ ) for WRF + CMAQ (top), WRF + CHIMERE (center) and difference between CMAQv4.5-CHIMERE2008b maximum SSA concentrations (bottom).

diameter were corrected in CMAQ, because a large fraction of the accumulation mode would fail below $2.5 \mu \mathrm{m}$ (Jiang et al., 2006; Kelly et al., 2010).

\subsection{Differences in the deposition results}

In practice there is little difference between the magnitudes of the dry deposition estimated with both equations, as shown in Fig. 6 for particles up to a radius of $10 \mu \mathrm{m}$ for the entire simulation.

The dry deposition fluxes are strongly correlated with the concentration of sea salt in those regions with high production, and the main difference comes from this point instead of the different schemes considered. The dry deposition pat- tern is rather similar for both schemes; generally, over the Mediterranean the dry deposition shows different seasonal maxima in the southern (Aegean Sea) and northern part (the Gulf of Lion and the Ligurian Sea) of the domain; however, CMAQ tends to provide larger amounts of SSA dry deposition over the Northern Mediterranean $\left(0.7-1.0 \mathrm{~g} \mathrm{~m}^{-2} \mathrm{yr}^{-1}\right)$, meanwhile the Southeastern Mediterranean accounts for the maximum annual dry deposition in the CHIMERE model $\left(0.9-1.5 \mathrm{~g} \mathrm{~m}^{-2} \mathrm{yr}^{-1}\right)$. The dry removal rate is dominated by the coarse aerosol component and essentially follows the surface drag stress patterns; the largest particles exhibit high deposition velocities due to the role of sedimentation (Foltescu et al., 2005). 

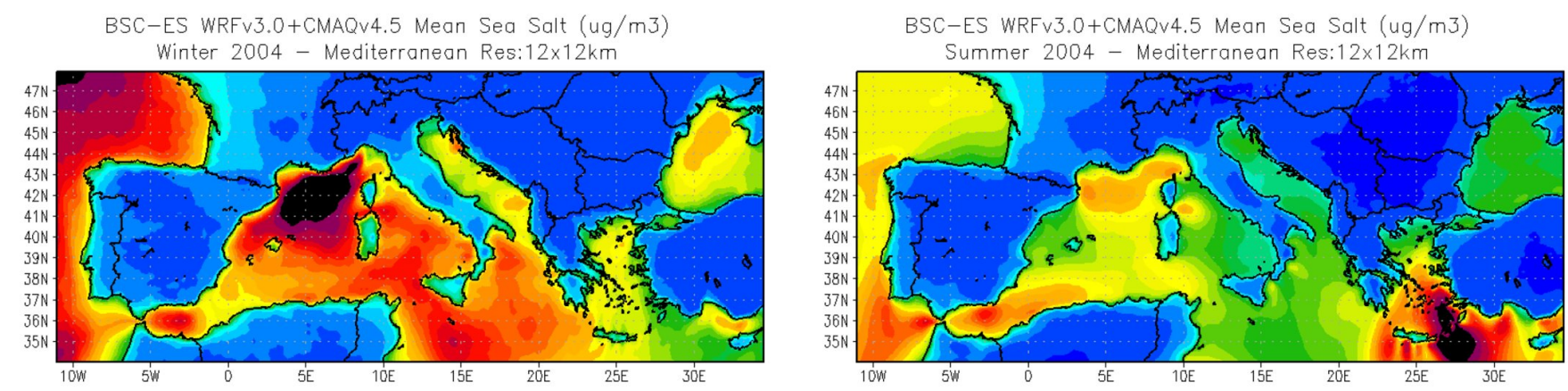

UMU-RAM WRFv3.0+CHIMERE2008b Mean Sea Salt (ug/m3) Winter 2004 - Mediterranean Res: $12 \times 12 \mathrm{~km}$

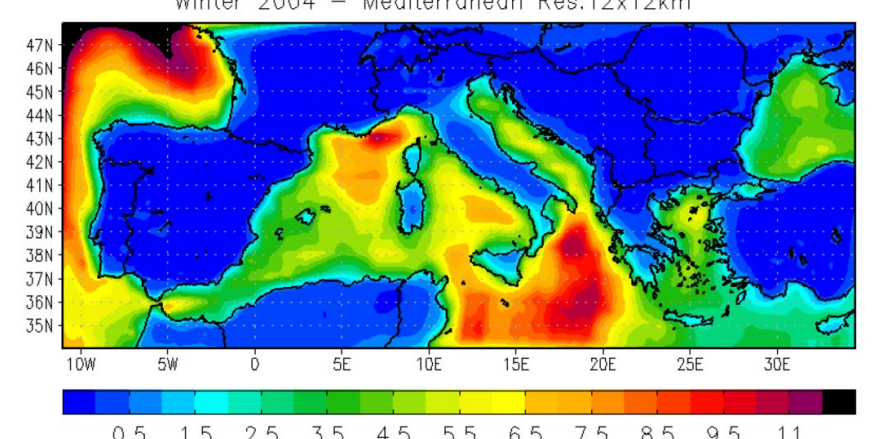

UMU-RAM WRFv3.0+CHIMERE2008b Mean Sea Salt (ug/m3) Summer 2004 - Mediterranean Res: $12 \times 12 \mathrm{~km}$

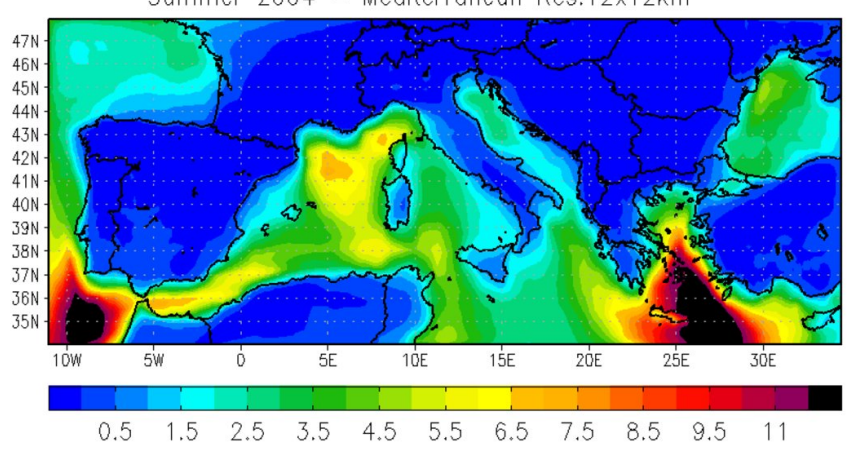

CMAQv4.5-CHIMERE2008b Mean Sea Salt Difference (ug/m3)

CMAQv4.5-CHIMERE2008b Mean Sea Salt Difference (ug/m3) Winter 2004 - Mediterranean Res:12×12km
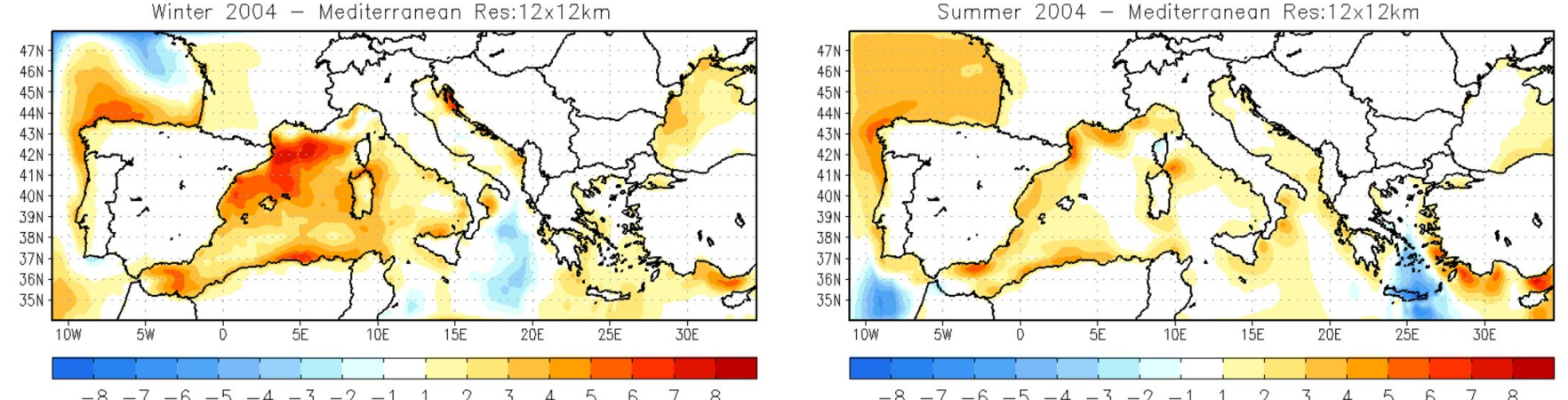

Fig. 4. (Left) modeled winter (DJF) mean SSA concentration $\left(\mu \mathrm{g} \mathrm{m}^{-3}\right.$ ) for WRF + CMAQ (top), WRF + CHIMERE (center) and difference between CMAQv4.5-CHIMERE2008b winter mean SSA concentrations (bottom); (right) modeled summer (JJA) mean SSA concentration $\left(\mu \mathrm{g} \mathrm{m}^{-3}\right.$ ) for WRF + CMAQ (top), WRF + CHIMERE (center) and difference between CMAQv4.5-CHIMERE2008b summer mean SSA concentrations (bottom).

\subsubsection{Wet deposition}

The wet deposition is more scattered than dry deposition over the continent. It is dominated by the accumulation mode and is strongly correlated to the precipitation patterns (Fig. 6). Over the Mediterranean, the wet deposition is maximum in wintertime and minimum in summer (not shown). As in the case of dry deposition, both schemes depict the wet deposition similarly. This wet scavenging is strongly dependent on precipitation frequency rather than precipitation amount, since wet deposition of coarse aerosols is highly efficient. For the wet annual deposition, the maximum values are located inland, especially over the Northern Iberian Peninsula $\left(0.85 \mathrm{~g} \mathrm{~m}^{-2} \mathrm{yr}^{-1}\right.$ in CMAQ for this area vs. $0.65 \mathrm{~g} \mathrm{~m}^{-2} \mathrm{yr}^{-1}$ in CHIMERE) and also in the Italian western coast and the Balkans littoral (around $0.5 \mathrm{~g} \mathrm{~m}^{-2} \mathrm{yr}^{-1}$ in both models).

Table 3 also shows the correlation between several meteorological variables and the concentration of SSA in different parts of the Mediterranean Sea. The largest correlation with the wind speed is found in the Alboran Sea $(0.88$ for CHIMERE and 0.81 for CMAQ). Generally, the correlation between the wind speed and the concentration of SSA is over 0.70 in all the seas ( $\approx 0.80$ for the entire domain) except in the Ionian sea, where this correlation is hardly above 0.60 in CMAQ scheme. In this target area, the deposition seems to strongly impact the concentration of SSA, since the 

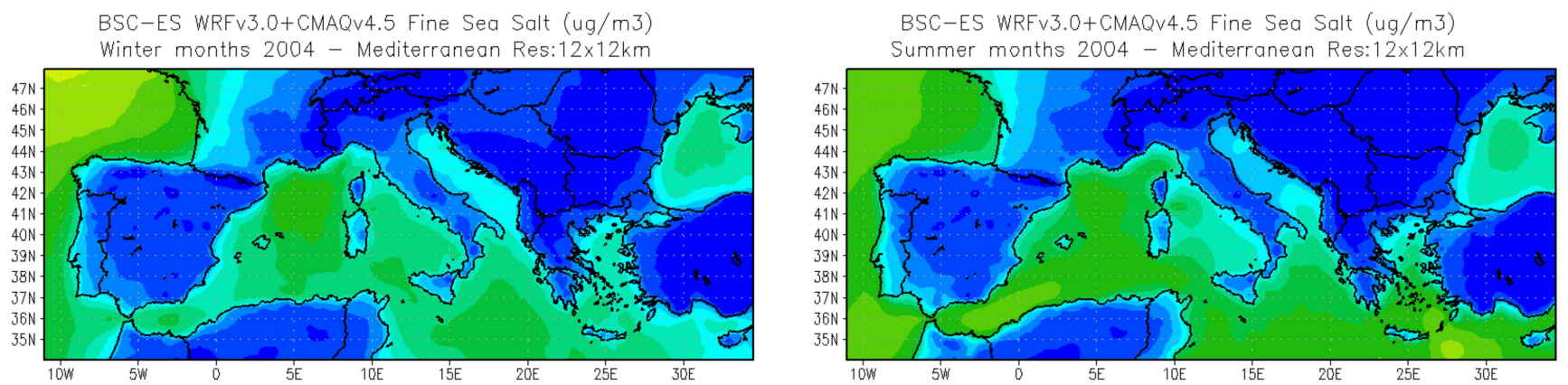

UMU-RAM WRFv3.0+CHIMERE2008b Fine Sea Salt (ug/m3)

Winter months 2004 - Mediterranean Res:12×12km

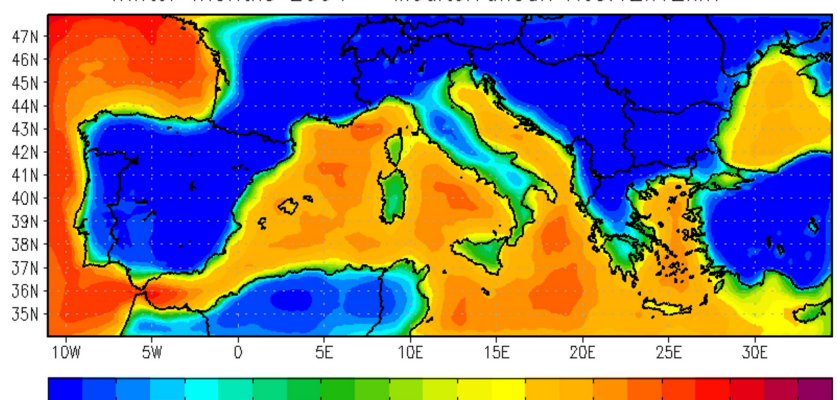

$\begin{array}{llllllllll}0.02 & 0.04 & 0.06 & 0.08 & 0.12 & 0.16 & 0.2 & 0.3 & 0.4 & 0.6\end{array}$

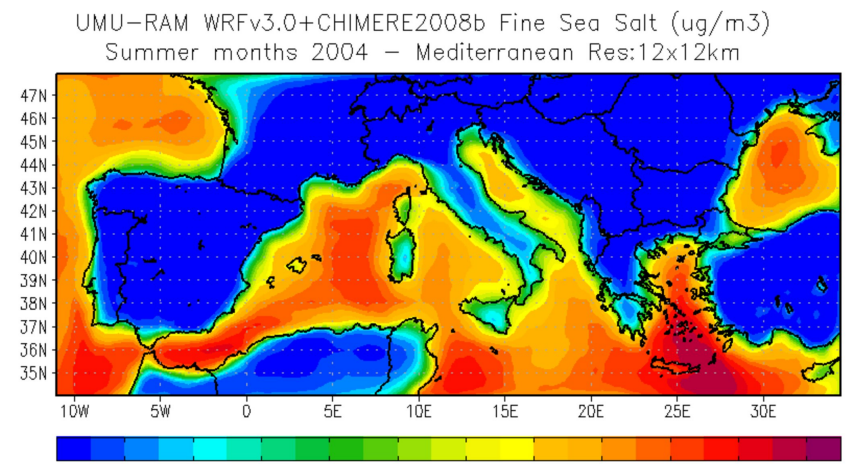

$\begin{array}{lllllllllll}0.02 & 0.04 & 0.06 & 0.08 & 0.12 & 0.16 & 0.2 & 0.3 & 0.4 & 0.6 & 1\end{array}$

Fig. 5. (Left) modeled winter (DJF) mean fine SSA concentration $\left(\mathrm{PM}_{2.5}\right)\left(\mu \mathrm{g} \mathrm{m}^{-3}\right)$ for WRF $+\mathrm{CMAQ}$ (top) and WRF $+\mathrm{CHIMERE}$ (bottom) simulations; (right) modeled summer (JJA) mean fine SSA concentration $\left(\mathrm{PM}_{2.5}\right)\left(\mu \mathrm{g} \mathrm{m}{ }^{-3}\right)$ WRF $+\mathrm{CMAQ}$ (top) and WRF + CHIMERE (bottom).

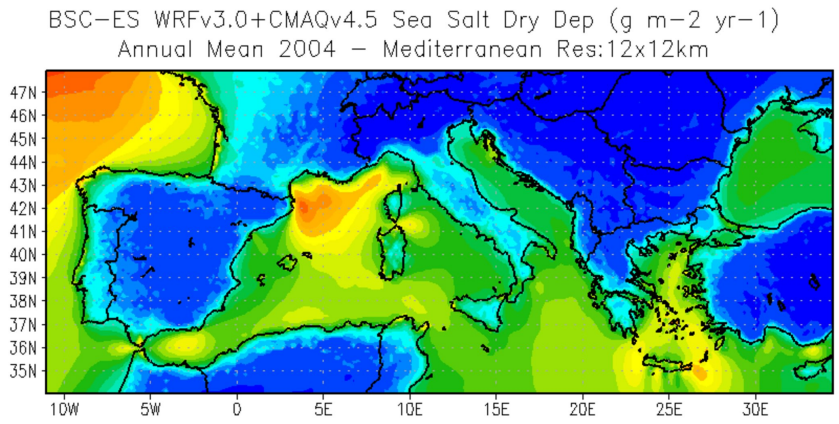

UMU-RAM WRFv3.0+CHIMERE2008b Sea Salt Dry Dep (g m-2 yr-1) Annual Mean 2004 - Mediterranean Res:12x12km

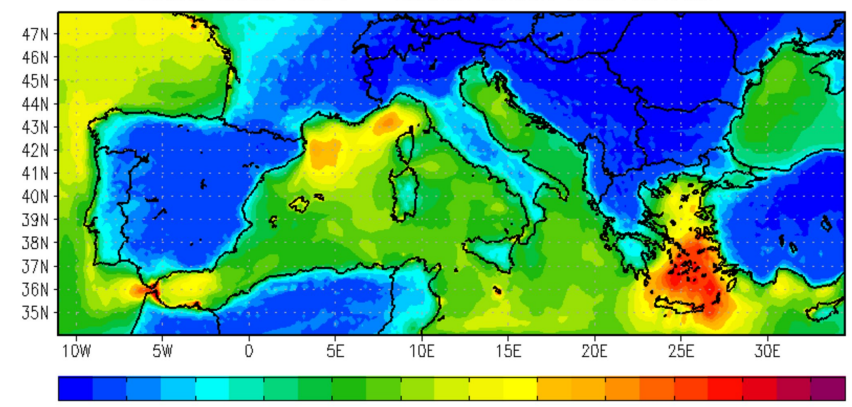

$\begin{array}{lllllllll}0.05 & 0.1 & 0.2 & 0.3 & 0.4 & 0.5 & 0.6 & 0.7 & 0.8\end{array}$
BSC-ES WRFv3.0+CMAQv4.5 Sea Salt Wet Dep ( $\mathrm{g} m-2 \mathrm{yr}-1)$

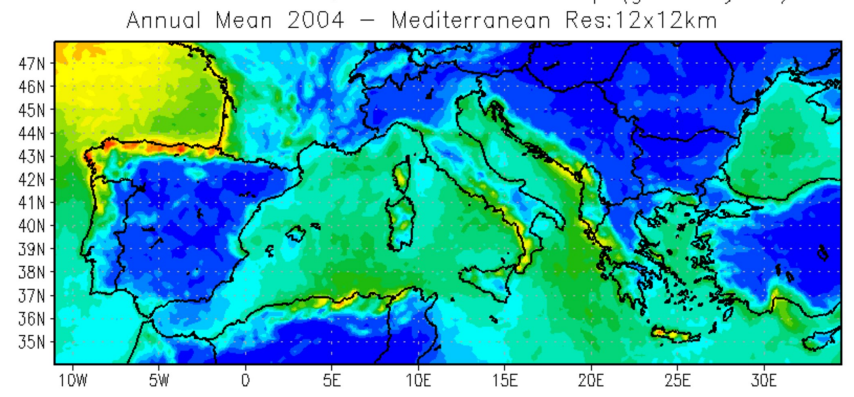

UMU-RAM WRFv3.0+CHIMERE2008b Sea Salt Wet Dep $(g \mathrm{~m}-2 \mathrm{yr}-1)$ Annual Mean 2004 - Mediterranean Res:12×12km

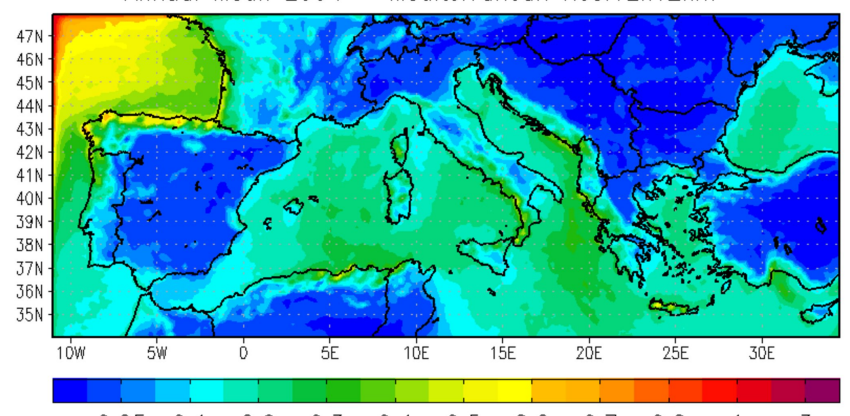

$\begin{array}{lllllllll}0.05 & 0.1 & 0.2 & 0.3 & 0.4 & 0.5 & 0.6 & 0.7 & 0.8\end{array}$

Fig. 6. Accumulated annual SSA deposition fluxes $\left(\mathrm{g} \mathrm{m}^{-2} \mathrm{yr}^{-1}\right)$ for WRF + CMAQ (top) and WRF + CHIMERE (bottom) simulations: (left) dry deposition (right) wet deposition. 
Table 3. Correlation of the sea-salt concentration (Conc) from CHIMERE and CMAQ models with different variables over small domains within the Mediterranean sea (wind speed, Wind; total deposition, Dep; and precipitation, Prec). Also, the dry deposition contribution over total deposition is shown (DryDep/Total).

\begin{tabular}{lrrrrrrrr}
\hline \multirow{2}{*}{ Domain } & \multicolumn{2}{c}{ Wind-Conc } & \multicolumn{2}{c}{ Dep-Conc } & \multicolumn{2}{c}{ Prec-Conc } & \multicolumn{2}{c}{ DryDep/Total } \\
\cline { 2 - 9 } & CHIM & CMAQ & CHIM & CMAQ & CHIM & CMAQ & CHIM & CMAQ \\
\hline Global & 0.78 & 0.80 & -0.65 & -0.64 & -0.43 & -0.41 & $61.97 \%$ & $57.22 \%$ \\
Tyrrhenian Sea & 0.71 & 0.76 & -0.78 & -0.82 & -0.52 & -0.52 & $62.36 \%$ & $62.12 \%$ \\
Adriatic Sea & 0.74 & 0.73 & -0.73 & -0.79 & -0.69 & -0.66 & $58.31 \%$ & $51.53 \%$ \\
Ionian Sea & 0.70 & 0.62 & -0.81 & -0.81 & -0.56 & -0.54 & $69.90 \%$ & $66.79 \%$ \\
Aegean Sea & 0.79 & 0.72 & -0.80 & -0.80 & -0.57 & -0.58 & $79.04 \%$ & $69.98 \%$ \\
Sardinia Sea & 0.80 & 0.81 & -0.79 & -0.79 & -0.62 & -0.57 & $74.68 \%$ & $72.08 \%$ \\
Alboran Sea & 0.89 & 0.81 & -0.73 & -0.73 & -0.70 & -0.66 & $79.45 \%$ & $76.21 \%$ \\
\hline
\end{tabular}

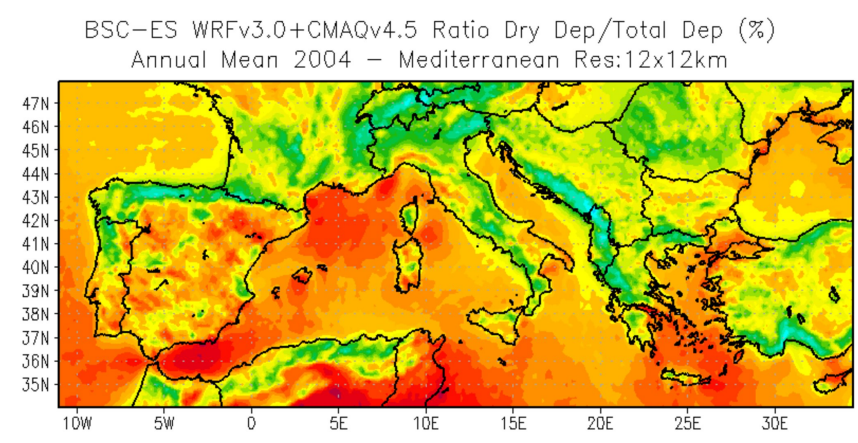

UMU-RAM WRFv3.0+CHIMERE2008b Ratio Dry Dep/Total Dep (\%) Annual Mean 2004 - Mediterranean Res:12×12km

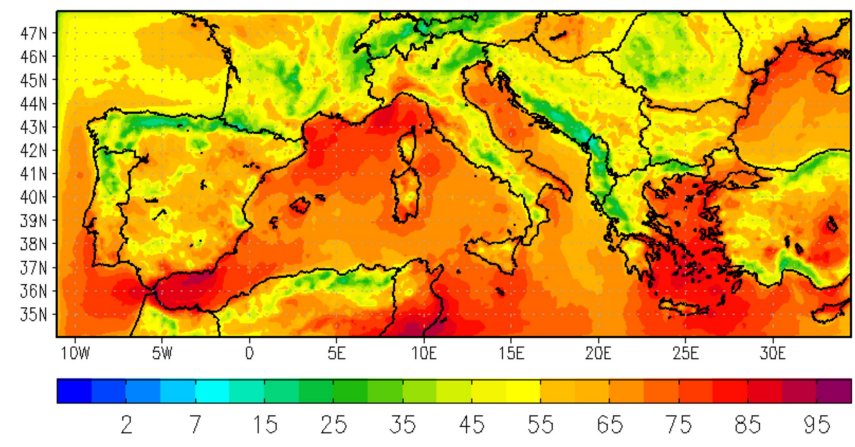

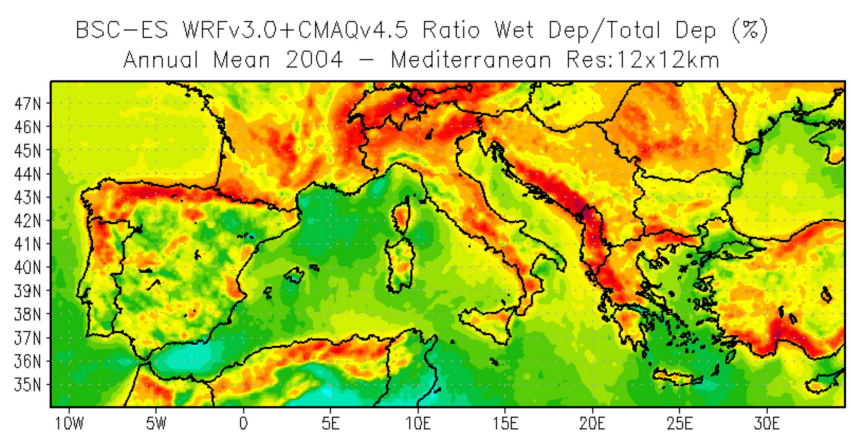

UMU-RAM WRFv3.0+CHIMERE2008b Ratio Wet Dep/Total Dep (\%) Annual Mean 2004 - Mediterranean Res:12x12km

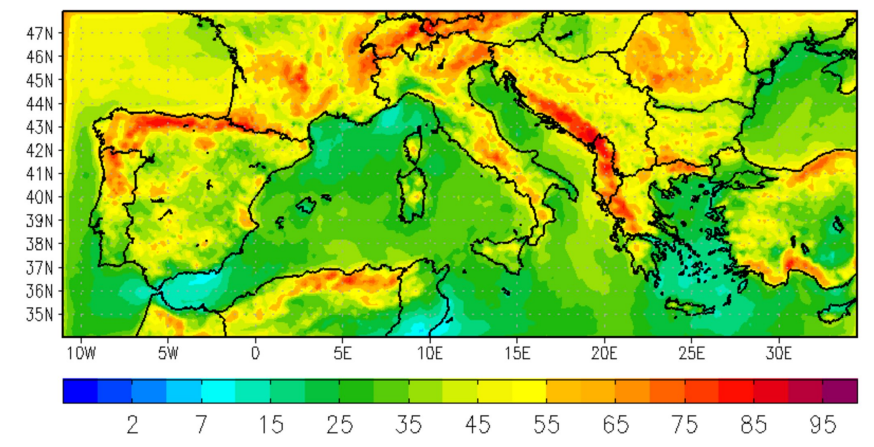

Fig. 7. (Left) ratio dry deposition/total deposition (\%) for WRF + CMAQ (top) and WRF + CHIMERE (bottom); (right) ratio wet deposition/total deposition (\%) for WRF + CMAQ (top) and WRF + CHIMERE (bottom).

anti-correlation of deposition with SSA levels is -0.80 for both schemes. Deposition seems to strongly influence the concentration of SSA, with anti-correlations ranging from -0.75 to -0.80 in all the sub-domains, being -0.65 if the entire domain of the simulations is analyzed. Similar values can be discussed for the correlation precipitation-concentration since precipitation influences total deposition. Here, correlation values are slightly lower $(-0.50$ to -0.70$)$ indicating the predominance of wet deposition in certain areas such as the Sardinia Sea or the Aegean Sea.
Figure 7 shows the percentage of the total deposition accounted by wet (large-scale and convective) and dry removal processes. The relative importance of wet and dry deposition of SSA depends strongly on particle size, and additionally on the meteorological conditions experienced by the particles subsequent to their production (Lewis and Schwartz, 2004). Consequently, this relative importance can vary greatly with season and location (Table 3). In general, the wet deposition is more intense in the CMAQ scheme over the coastal mountain chains, where wet deposition represents over $85 \%$ of the total deposition in CMAQ and less than $75 \%$ in CHIMERE. 
The overall dry deposition of sea salt over the model domain represents about $62 \%$ and $57 \%$ of the total deposition in CHIMERE and CMAQ models, respectively. Hence, in our target domain dry deposition is more important than wet deposition, similar to Mahowald et al. (2006) and Gong et al. (1997). The percentage of dry deposition is maximum over the Aegean Sea and the Alboran Sea (around 79\% in CHIMERE and over $70 \%$ in CMAQ).The lowest weight of dry deposition is found in the Tyrrhenian and Adriatic Seas. This feature is very well captured by both models and the value compares well between models (62 and $58 \%$ in CHIMERE and 62 and $51 \%$ in CMAQ). As stated by Zakey et al. (2008), the larger removal rates by wet deposition in the Northern Mediterranean are caused by the strong storms occurring in spring and autumn in the upper Tyrrhenian and Adriatic Seas, where wet deposition accounts for $40-50 \%$ of the total annual deposition.

\section{Conclusions}

The modeling of the processes impacting sea-salt aerosol (SSA) concentrations remains still a challenge and an important source of uncertainty in air quality modeling. Hence, this work compares two different algorithms implemented in CHIMERE and CMAQ chemistry transport models for representing SSA, highlighting the main differences found between them. The results have been preliminary evaluated against Aeronet and ground-based measurements, showing that both schemes reproduce accurately the spatial gradients, the patterns and the dynamics observed in the Mediterranean SSA. The models highlight the non-uniform behavior of SSA in the Mediterranean basin, showing a strong seasonality.

The levels of SSA vary strongly across the Western and the Eastern Mediterranean, reproducing CHIMERE higher levels in the Aegean Sea $\left(12 \mu \mathrm{g} \mathrm{m}^{-3}\right)$ and CMAQ in the Gulf of Lion $\left(9 \mu \mathrm{g} \mathrm{m}^{-3}\right)$. The maximum concentrations do not show a clear pattern, with the highest modeled SSA concentrations located over open ocean (Atlantic and Mediterranean, above $55 \mu \mathrm{g} \mathrm{m}^{-3}$ reproduced by CMAQ). These differences may come from the RH correction introduced in the CMAQ scheme, that is not that sophisticated in the parameterization included within CHIMERE. Also, a large difference is found for the ratio $\mathrm{PM}_{2.5} /$ total SSA in CMAQ and CHIMERE (much lower for the former) because of the discrepancy between the source functions in sea spray fluxes for small droplets; furthermore, transfer from $\mathrm{PM}_{10}$ to $\mathrm{PM}_{2.5}$ is not considered in the implemented version of CMAQ.

Regarding deposition, despite CMAQ dry deposition scheme trusted a parameterization based on a non-electrical analogy, the results indicate that the dry removal rates are very similar for both models despite the different schemes implemented. Dry deposition is dominated by the coarse aerosol component and essentially follows the surface drag stress patterns in both models. On the other hand, the wet deposition is more scattered than dry deposition over the continent since it depends essentially on the precipitation rate for both schemes. Hence, the wet deposition is dominated by the accumulation mode and is strongly correlated to the precipitation patterns provided by the WRF-ARW meteorological driver.

The results from the model validation indicate that there is not a direct relationship between an overestimation of the wind speed and a corresponding overestimation of the fluxes (SSA levels tend to be slightly underestimated in both models). The causes for this behavior should be further explored. Even if we do not take into account the rest of the processes involved in a chemistry transport model, the sea-salt fluxes respond to certain parameterizations and empirical or semiempirical relationships that may not accurately represent the sea-salt fluxes for the conditions studied in this work. In other words, overestimating the wind speed does not necessarily lead to an overestimation of the flux. Moreover, the slight underestimations observed for SSA in both models can be caused by a large number of circumstances: errors in the prediction of the mixing height (leading to a larger dilution), problems with the horizontal or vertical discretization of the models, overestimations in the dry and wet deposition (which is hard to evaluate over the Mediterranean Sea), misrepresentations of the aerosol radius, uncertainties in the settling velocities, etc. Hence, in this comparison we have tried to find the global causes for the differences between schemes as implemented in the corresponding chemistry transport models, not between the theoretical schemes.

Summarizing, the discrepancies in SSA modeled levels between CHIMERE and CMAQ transport models may be explained by some important differences found between the models themselves: CHIMERE sectional approach vs. CMAQ modal aerosol module; the different treatment for particle sizes, the source functions (more refined and sophisticated in CMAQ than in CHIMERE) and the diverse approached followed for deposition, which has a more limited influence. The results constitute a step towards the understanding of the SSA dynamics in a complex area as the Mediterranean, where the sea salt plays an important role in a number of physical and chemical atmospheric processes.

Acknowledgements. This work was funded by the Spanish Ministry of the Environment (project ESCENA and CALIOPE), Fundación Seneca (Ref. 12033/PI/09); and projects CGL-2008-02818, CGL2010-22158-C02-02 and the Ramón y Cajal Programme of the Spanish Ministry of Science. Simulations were carried out in the MareNostrum supercomputer (Barcelona Supercomputing Center-Centro Nacional de Supercomputacion, www.bsc.es) and the Ben Arabi supercomputer hold by the Centro de Supercomputacion de Murcia-Fundacion Parque Cientifico de Murcia (www.cesmu.es).

Edited by: A. Pszenny 


\section{References}

Alpert, P. and Ganor, E.: A jet stream associated heavy dust storm in the Western Mediterranean, J. Geophys. Res., 98, 7339-7349, doi:10.1029/92JD01642, 1993.

Athanasopoulou, E., Tombrou, M., Pandis, S. N., and Russell, A. G.: The role of sea-salt emissions and heterogeneous chemistry in the air quality of polluted coastal areas, Atmos. Chem. Phys., 8, 5755-5769, doi:10.5194/acp-8-5755-2008, 2008.

Baldasano, J. M., Jiménez-Guerrero, P., Jorba, O., Pérez, C., López, E., Güereca, P., Martín, F., Vivanco, M. G., Palomino, I., Querol, X., Pandolfi, M., Sanz, M. J., and Diéguez, J. J.: Caliope: an operational air quality forecasting system for the Iberian Peninsula, Balearic Islands and Canary Islands - first annual evaluation and ongoing developments, Adv. Sci. Res., 2, 89-98, doi:10.5194/asr-2-89-2008, 2008.

Baldasano, J. M., Pay, M. T., Jorba, O, Gassó, S., and JiménezGuerrero, P.: An annual assessment of air quality with the CALIOPE modeling system over Spain, Sci. Total Environ., 11, 2163-2178, doi:10.1016/j.scitotenv.2011.01.041, 2011.

Bessagnet, B., Hodzic, A., Vautard, R., Beekmann, M., Cheinet, S., Honore, C., Liousse, C., and Rouil, L.: Aerosol modeling with CHIMERE - preliminary evaluation at the continental scale, Atmos. Environ., 38, 2803-2817, 2004.

Bessagnet, B., Khvorostayanov, L., Menut, K., Monge, J. L., and Vautard, R.: Documentation of the chemistry-transport model CHIMERE. Institute Pierre Simon Laplace, INERIS, LISA, june 2009 edition, p. 158 , 2009.

Binkowski, F. S.: Aerosols in models-3 CMAQ, in: Science Algorithms of the EPA Models-3 Community Multiscale Air Quality (CMAQ) Modeling System, edited by: Byun, D. W. and Ching, J. K. S., US Environmental Protection Agency (EPA), Wahsington, DC, 1000-1023, 1999.

Binkowski, F. S. and Roselle, S. J.: Models-3 Community Multiscale Air Quality (CMAQ) model aerosol component, 1. model description, J. Geophys. Res., 108(D6), 4183, doi:10.1029/2001JD001409, 2003.

Binkowski, F. S. and Shankar, U.: The regional particulate matter model, 1. model description and preliminary results, J. Geophys. Res., 100, 191-206, 1995.

Boylan, J. and Russell, A.: PM and light extinction model performance: metrics, goals and criteria for three-dimensional air quality models, Atmos. Environ., 40, 4946-4959, 2006.

Byun, D. and Schere, K. L.: Review of the governing equations, computational algorithms, and other components of the Models3 Community Multiscale Air Quality (CMAQ) modeling system, Appl. Mech. Rev., 59(2), 51-77, 2006.

Camuffo, D., Secco, C., Brimblecombe, P., and Martin-Vide, J.: Sea storms in the Adriatic Sea and the Western Mediterranean during the last millennium, Climatic Change, 46, 209-223, doi:10.1023/A: 1005607103766, 2000.

Cavaleri, L.: The wind and wave atlas of the Mediterranean Sea - the calibration phase, Adv. Geosci., 2, 255-257, doi:10.5194/adgeo-2-255-2005, 2005.

Chang, J. S., Brost, R. A., Isaksen, I. S. A., Madronich, S., Middleton, P., Stockwell, W. R., and Walcek, C. J.: A three-dimensional Eulerian acid deposition model: physical concepts and formulation, J. Geophys. Res., 92, 14681-14700, 1987.

Cherubini, T., Ghelli, A., and Lalaurette, F.: Verification of pre- cipitation forecasts over the Alpine region using a high-density observing network, Weather Forecast., 17, 238-249, 2002.

Clarke, A. D., Owens, S. R., and Zhou, J.: An ultrafine sea-salt flux from breaking waves: implications for cloud condensation nuclei in the remote marine atmosphere, J. Geophys. Res., 111, D06202, doi:10.1029/2005JD006565, 2006.

De Leeuw, G., Neele, F. P., Hill, M., Smith, M. H., and Vignati, E.: Production of sea spray aerosol in the surf zone, J. Geophys. Res., 105(D24), 29397-29410, 2000.

Derognat, C., Beekmann, M., Baeumle, M., Martin, D., and Schmidt, H.: Effect of biogenic volatile organic compound emissions on tropospheric chemistry during the Atmospheric Pollution Over the Paris Area (ESQUIF) campaign in the Ile-de-France region, J. Geophys. Res., 108(D17), 8560, doi:10.1029/2001JD001421, 2003.

Dudhia, J.: Numerical study of convection observed during the winter monsoon experiment using a mesoscale two-dimensional model, J. Atmos. Sci., 46(20), 3077-3107, 1989.

Dyer, A. J. and Hicks, B. B.: Flux-gradient relationships in the constant flux layer, Q. J. Roy. Meteor. Soc., 96(410), 715-721, 1970.

Easter, R. C., Ghan, S. J., Zhang, Y., Saylor, R. D., Chapman, E. G., Laulainen, N. S., Abdul-Razzak, H., Leung, H. R., Bian, X. D., and Zaveri, R. A.: MIRAGE: model description and evaluation of aerosols and trace gases, J. Geophys. Res., 109, D20210, doi:10.1029/2004JD004571, 2004.

Ebert, E. E., Damrath, U., Wergen, W., and Baldwin, M. E.: The WGNE assessment of shortterm quantitative precipitation forecasts, B. Am. Meteorol. Soc., 84, 481-492, 2003.

Elleman, R. A. and Covert, D. S.: Aerosol size distribution modeling with the Community Multiscale Air Quality modeling system (CMAQ) in the Pacific Northwest: 1. model comparison to observations, J. Geophys. Res., 114, D11206, doi:10.1029/2008JD010791, 2009.

Folberth, G. A., Hauglustaine, D. A., Lathière, J., and Brocheton, F.: Interactive chemistry in the Laboratoire de Météorologie Dynamique general circulation model: model description and impact analysis of biogenic hydrocarbons on tropospheric chemistry, Atmos. Chem. Phys., 6, 2273-2319, doi:10.5194/acp-62273-2006, 2006.

Foltescu, V. L., Pryor, S. C., and Bennet, C.: Sea salt generation, dispersion and removal on the regional scale, Atmos. Environ., 39, 2123-2133, doi:10.1016/j.atmosenv.2004.12.030, 2005.

Gerber, H.: Relative-humidity parameterization of the navy aerosol model (NAM). Tech. Rep. 8956, National Research Laboratory, Washington, D. C., 1985.

Gery, M. W., Whitten, G. Z., Killus, J. P., and Dodge, M. C.: A photochemical kinetics mechanism for urban and regional scale computer modeling, J. Geophys. Res., 94(D10), 1292512956, 1989.

Giorgi, F.: A particle dry deposition scheme for use in tracer transport models, J. Geophys. Res., 91, 9794-9806, 1986.

Gong, S. L.: A parameterization of sea-salt aerosol source function for sub- and super-micron particles, Global Biogeochem. Cy., 17(4), 1097, doi:10.1029/2003GB002079, 2003.

Gong, S. L., Barrie, L. A., and Blanchet, J.-P.: Modeling sea-salt aerosols in the atmosphere 1. model development, J. Geophys. Res., 102(D3), 3805-3818, 1997.

Guelle, W., Balkanski, Y. J., Dibb, J. E., Schulz, M., and Dulac, F.: Wet deposition in a global size-dependent aerosol trans- 
port model. 2. influence of the scavenging scheme on $\mathrm{Pb}$ vertical profiles and deposition, J. Geophys. Res., 103(D22), 2887528891, 1998.

Gong, S. L., Barrie, L. A., and Lazare, M.: Canadian Aerosol Model (CAM): a size-segregated simulation of atmospheric aerosol process for climate and air quality models. 2. global sea-salt aerosol and its budgets, J. Geophys. Res., 107(D24), 4779, doi:10.1029/2001JD002004, 2002.

Haywood, J., Ramaswamy, V., and Soden, B.: Tropospheric aerosol climate forcing in clear-sky satellite observation over the oceans, Science, 283, 1299-1303, doi:10.1126/science.283.5406.1299, 1999.

Hauglustaine, D. A., Hourdin, F., Jourdain, L., Filiberti, M. A., Walters, S., Lamarque, J. F., and Holland, E. A.: Interactive chemistry in the Laboratoire de Meteorologie Dynamique general circulation model: description and background tropospheric chemistry evaluation, J. Geophys. Res., 109(D4), D04314, doi:10.1029/2003JD003957, 2004.

Holben, B. N., Tanre, D., Smirnov, A., Eck, T. F., Slutsker. I., Abujassan, N., Newcomb, W. W., Schafer, J. S., Chatenet, B., Lavenu, F., Kaufman, Y. J., Vande Castle, J., Setzer, A., Markham, B., Clark, D., Frouin, R., Halthore, R., Karnell, A., O’Neill, N. T., Pietras, C., Pinker, R. T., Voss, K., and Zibordi, G.: An emerging ground-based aerosol climatology: aerosol optical depth from Aeronet, J. Geophys. Res., 106(D11), 1206712097, doi:10.1029/2001JD900014, 2001.

Hong, S. Y., Dudhia, J., and Chen, S. H.: A revised approach to ice microphysical processes for the bulk parameterization of clouds and precipitation, Mon. Weather Rev., 132(1), 103-120, doi: 10.1175/1520-0493(2004)132;0103:ARATIM $2.0 . C O ; 2,2004$.

Hueglin, C., Gehrig, R., Baltensperger, U., Gysel, M., Monn, C., and Vonmont, H.: Chemical characterisation of $\mathrm{PM}_{2.5}, \mathrm{PM}_{10}$ and coarse particles at urban, near-city and rural sites in Switzerland, Atmos. Environ., 39, 637-651, 2005.

Jiang, W., Smith, S., Giroux, E., Roth, H., and Yin, D.: Differences between CMAQ fine mode particle and $\mathrm{PM}_{2.5}$ concentrations and their impact on model performance evaluation in the lower Fraser Valley, Atmos. Environ., 40(26), 4973-4985, 2006.

Jiménez, P., Baldasano, J. M., and Dabdub, D.: Comparison of photochemical mechanisms for air quality modelling, Atmos. Environ., 37(30), 4179-4194, doi:10.1016/S1352-2310(03)00567-3, 2003.

Kain, J. S. and Fritsch, J. M.: A one-dimensional entraining/detraining plume model and its application in convective parameterization, J. Atmos. Sci., 47(23), 2784-2802, doi:10.1175/1520-0469(1990)047;2784:AODEPM $i 2.0 . C O ; 2$, 1990.

Kain, J. S. and Fritsch, J. M.: Convective parameterization for mesoscale models: the Kain-Fritsch scheme, in: The representation of cumulus convection in numerical models, edited by: Emanuel, K. A. and Raymond, D. J., American Meteorological Society, Boston, 165-170, 1993.

Kelly, J. T., Bhave, P. V., Nolte, C. G., Shankar, U., and Foley, K. M.: Simulating emission and chemical evolution of coarse sea-salt particles in the Community Multiscale Air Quality (CMAQ) model, Geosci. Model Dev., 3, 257-273, doi:10.5194/gmd-3-257-2010, 2010.

Kim, Y. P., Seinfeld, J. H., and Saxena, P.: Atmospheric gas-aerosol equilibrium. I: thermodynamics model, Aerosol Sci. Tech., 19,
157-181, 1993.

Kishcha, P., Nickovic, S., Luvchik, A., Janjic, Z., Perez, N., Viana, M., Mihalopoulos, N., Mamane, M., Yossef, O., and Alpert, P.: Sea-salt aerosol forecasts over the Mediterranean Sea, in: Air Pollution Modeling and its Application XX, edited by: Steyn, D. W. and Rao, S. T., The NATO Science for Peace and Security Programme, Springer, San Francisco, 2009.

Knipping, E. M. and Dabdub, D.: Impact of chlorine emissions from sea-salt aerosol on coastal urban ozone, Environ. Sci. Technol., 37, 275-284, 2003.

Lewis, E. R. and Schwartz, S. E.: Sea salt aerosol production: mechanisms, methods, measurements, and models - a critical review, Geophys. Monogr. Ser., vol. 152, AGU, Washington, DC, 2004.

Loosmore, G. and Cederwall, R.: Precipitation scavenging of atmospheric aerosols for emergency response applications: testing an updated model with new real-time data, Atmos. Environ., 38, 993-1003, 2004.

Malm, W. C., Sisler, J. F., Huffman, D., Eldred, R. A., and Cahill, T. A.: Spatial and seasonal trends in particle concentration and optical extinction in the United States, J. Geophys. Res., 99, 1347-1370, 1994.

Manders, A. M. M., Schap, M., Querol, X., Albert, M. F., Vercauteren, J., Kuhlbusch, T. A. J., and Hoogerbrugge, R.: Sea salt concentrations across the European continent, Atmos. Environ., 44, 2434-2442, doi:10.1016/j.atmosenv.2010.03.028, 2010.

Martensson, E. M., Nilsson, E. D., Leeuw, G. D., Cohen, L. H., and Hansson, H. C.: Laboratory simulations and parameterization of the primary marine aerosol production, J. Geophys. Res., 108(D9), 4297, doi:10.1029/2002JD002263, 2003.

Matthias, V., Aulinger, A., and Quante, M.: Adapting CMAQ to investigate air pollution in North Sea coastal regions, Environ. Modell. Softw., 23(3), 356-368, 2008.

Michalakes, J., Dudhia, J., Gill, D., Henderson, T., Klemp, J., Skamarock, W., and Wang, W.: The weather research and forecast model: software architecture and performance, in: Proceeding of the Eleventh ECMWF Workshop on the Use of High Performance Computing in Meteorology, Reading, UK, 25-29 October 2004, edited by: Zwieflhofer, W., and Mozdzynski, World Scientific, Reading (UK), 117-124, 2004.

Ma, X., von Salzen, K., and Li, J.: Modelling sea salt aerosol and its direct and indirect effects on climate, Atmos. Chem. Phys., 8, 1311-1327, doi:10.5194/acp-8-1311-2008, 2008.

Mahowald, N., Lamarque, J.-F., Tie, X. X., and Wolff, E.: Seasalt aerosol response to climate change: Last Glacial Maximum, preindustrial, and doubled carbon dioxide climates, J. Geophys. Res., 111, D05303, doi:10.1029/2005JD006459, 2006.

Mlawer, E. J., Taubman, S. J., Brown, P. D., Iacono, M. J., and Clough, S. A.: Radiative transfer for inhomogeneous atmosphere: RRTM, a validated correlated-k model for the longwave, J. Geophys. Res., 102(D14), 16663-16682, 1997.

Monahan, E. C.: Coastal Aerosol Workshop Proceedings, edited by: Goroch, A. K. and Geernaert, G. L., Rep. NRL/MR/7542 95-7219, Nav. Res. Lab., Monterey, California, 138 pp., 1995.

Monahan, E. C., Spiel, D. E., and Davidson, K. L.: A model of marine aerosol generation via whitecaps and wave disruption, in: Oceanic Whitecaps, edited by: Monahan, E. C. and Niocaill, G. M., Reidel, Norwell, Mass, 167-174, 1986.

Nenes, A., Pilinis, C., and Pandis, S. N.: ISORROPIA: a new 
thermodynamic equilibrium model for multiphase multicomponent inorganic aerosols, Aquat. Geochem., 4(1), 123-152, doi:10.1023/A:1009604003981, 1998.

Nolte, C. N., Bhave, P. V., Arnold, J. R., Dennis, R. L., Zhang, K. M., and Wexler, A. S.: Modeling urban and regional aerosols - application of the CMAQ-UCD aerosol model to Tampa, a coastal urban site, Atmos. Environ., 42, 3179-3191, 2008.

Noh, Y., Cheon, W. G., Hong, S. Y., and Raasch, S.: Improvement of the $k$-profile model for the planetary boundary layer based on large eddy simulation data, Bound.-Lay. Meteorol., 107(2), 401427, doi:10.1023/A:1022146015946, 2003.

Paulson, C. A.: The mathematical representation of wind speed and temperature profiles in the unstable atmospheric surface layer, J. Appl. Meteorol., 9(6), 857-861, 1970.

Peters, K. and Eiden, R.: Modelling the dry deposition velocity of aerosol particles to a spruce forest, Atmos. Environ., 26(14), 2555-2564, 1992.

Puxbaum, H., Gomiscek, B., Kalina, M., Bauer, H., Salam, A., Stopper, S., Preining, O., and Hauck, H.: A dual site study of $\mathrm{PM}_{2.5}$ and $\mathrm{PM}_{10}$ aerosol chemistry in the larger region of $\mathrm{Vi}$ enna, Austria, Atmos. Environ., 38, 3949-3958, 2004.

Pay, M. T., Piot, M., Jorba, O., Gasso, S., Goncalves, M., Basart, S., Dabdub, D., Jimenez-Guerrero, P., and Baldasano, J. M.: A full year evaluation of the CALIOPE-EU air quality modeling system over Europe for 2004, Atmos. Environ., 44, 3322-3342, doi:10.1016/j.atmosenv.2010.05.040, 2010.

Querol, X., Alastuey, A., Pey, J., Cusack, M., Pérez, N., Mihalopoulos, N., Theodosi, C., Gerasopoulos, E., Kubilay, N., and Koçak, M.: Variability in regional background aerosols within the Mediterranean, Atmos. Chem. Phys., 9, 4575-4591, doi:10.5194/acp-9-4575-2009, 2009.

Rodriguez, S., Querol, X., Alastuey, A., Viana, M. M., Alarcon, M., Mantilla, E., and Ruiz, C. R.: Comparative $\mathrm{PM}_{10}-\mathrm{PM}_{2.5}$ source contribution study at rural, urban and industrial sites during PM episodes in Eastern Spain, Sci. Total Environ., 328, 95-113, 2004.

Rouil, L., Honore, C., Vautard, R., Beekmann, M., Bessagnet, B., Malherbe, L., Meleux, F., Dufour, A., Elichegaray, C., Flaud, J.M., Menut, L., Martin, D., Peuch, A., Peuch, V.-H., and Poisson, N.: PREV'AIR, an operational forecasting and mapping system for air quality in Europe, B. Am. Meteorol. Soc., 90, 7383, 2009.

Saaroni, H., Ziv, B., Bitan, A., and Alpert, P.: Easterly wind storms over Israel, Theor. Appl. Climatol., 59, 61-77, doi:10.1007/s007040050013, 1998.

Salvador, P., Artiñano, B., Querol, X., Alastuey, A., and Costoya, M.: Characterisation of local and external contribution of atmospheric particulate matter at a background coastal site, Atmos. Environ., 41, 1-17, 2007.

Seinfeld, J. H. and Pandis, S. N.: Atmospheric Chemistry and Physics: from Air Pollution to Climate Change, WileyInterscience, NJ, 1997.

Solmon, F., Giorgi, F., and Liousse, C.: Aerosol modeling for regional climate studies: application to anthropogenic particles and evaluation over a European/African domain, Tellus B, 58(1), 5172, 2006.

Skamarock, W. C. and Klemp, J. B.: A time-split nonhydrostatic atmospheric model for weather research and fore- casting applications, J. Comput. Phys., 227(7), 3465-3485, doi:10.1016/j.jcp.2007.01.037, 2008.

Smirnov, A., Holben, B. N., Kaufman, Y. J., Dubovik, O., Eck, T. F., Slutsker, I., Pietras, C., and Halthore, R. N.: Optical properties of atmospheric aerosol in maritime environments, J. Atmos. Sci., 59, 501-523, 2002.

Szopa, S., Foret, G., Menut, L., and Cozic, A.: Impact of large scale circulation on european summer surface ozone and consequences for modelling forecast, Atmos. Environ., 43, 1189-1195, 2009.

Tang, I. N., Wong, W. T., and Munkelwitz, H. R.: The relative importance of atmospheric sulfates and nitrates in visibility reduction, Atmos. Environ., 14, 2463-2471, 1981.

Tang, I. N.: Chemical and size effects of hygroscopic aerosols on light scattering coefficients, J. Geophys. Res., 101, 1924519250, 1996.

Tindale, N. W. and Pease, P. P.: Aerosols over the Arabian Sea: atmospheric transport pathways and concentrations of dust and sea salt, Deep-Sea Res. Pt. II, 46, 1577-1595, doi:10.1016/S09670645(99)00036-3, 1999.

Textor, C., Schulz, M., Guibert, S., Kinne, S., Balkanski, Y., Bauer, S., Berntsen, T., Berglen, T., Boucher, O., Chin, M., Dentener, F., Diehl, T., Easter, R., Feichter, H., Fillmore, D., Ghan, S., Ginoux, P., Gong, S., Grini, A., Hendricks, J., Horowitz, L., Huang, P., Isaksen, I., Iversen, I., Kloster, S., Koch, D., Kirkevåg, A., Kristjansson, J. E., Krol, M., Lauer, A., Lamarque, J. F., Liu, X., Montanaro, V., Myhre, G., Penner, J., Pitari, G., Reddy, S., Seland, Ø., Stier, P., Takemura, T., and Tie, X.: Analysis and quantification of the diversities of aerosol life cycles within AeroCom, Atmos. Chem. Phys., 6, 1777-1813, doi:10.5194/acp-6-1777-2006, 2006.

Tsyro, S.: First Estimates of the Effect of Aerosol Dynamics in the Calculation of $\mathrm{PM}_{10}$ and $\mathrm{PM}_{2.5}$, EMEP report, edited by the Norwegian Meteorological Institute, Oslo, Norway, 2002.

Venkatram, A. and Pleim, J.: The electrical analogy does not apply to modeling dry deposition of particles, Atmos. Environ., 33, 3075-3076, 1999.

Viana, M., Querol, X., Ballester, F., Llop, S., Esplugues, A., Fernandez Patier, R., Garcia Dos Santos, S., and Herce, M. D.: Characterising exposure to PM aerosols for an epidemiological study, Atmos. Environ., 42, 1552-1568, 2008.

Vinoj, V. and Satheesh, S. K.: Direct and indirect radiative effects of sea-salt aerosols over Arabian Sea, Curr. Sci. India, 86(10), 1381-1390, 2004.

Visser, H., Buringh, E., and van Breugel, P. B.: Composition and Origin of Airborne Particulate Matter in The Netherlands, Report 650010029, National Institute for Public Health and the Environment, RIVM, Bilthoven, The Netherlands, 104 pp., 2001.

Webb, E. K.: Profile relationships: the log-linear range, and extension to strong stability, Q. J. Roy. Meteorol. Soc., 96(407), 67-90, doi:10.1002/qj.49709640708, 1970.

Wesely, M.: Parameterization of surface resistances to gaseous dry deposition in regional scale numerical models, Atmos. Environ., 23, 1293-1304, 1989.

Wilks, D. S.: Statistical Methods in the Atmospheric Sciences, An Introduction, Academic Press, San Diego, 467 pp., 1995.

Willmott, C. J., Ackleson, S. G., Davis, R. E., Feddema, J. J., Klink, K. M., Legates, D. R., O'Donnell, J., and Rowe, C. M.: Statistics for the evaluation and comparison of models, J. Geophys. Res., 90, 8995-9005, 1985. 
Zhang, L., Gong, S., Padro, J., and Barrie, L.: A size-segregated particle dry deposition scheme for an atmospheric aerosol module, Atmos. Environ., 35, 549-560, 2001.

Zhang, K. M., Knipping, E. M., Wexler, A. S., Bhave, P. V., and Tonnesen, G. S.: Size distribution of sea-salt emissions as a function of relative humidity, Atmos. Environ., 39, 3373-3379, 2005.

Zakey, A. S., Solmon, F., and Giorgi, F.: Implementation and testing of a desert dust module in a regional climate model, Atmos. Chem. Phys., 6, 4687-4704, doi:10.5194/acp-6-4687-2006, 2006.
Zhang, K. M., Knipping, E. M., Wexler, A. S., Bhave, P. V., and Tonnesen, G. S.: Reply to comment on "Size distribution of seasalt emissions as a function of relative humidity", Atmos. Environ., 40, 591-592, 2006.

Zhang, Y., Liu, P., Pun, B., and Seigneur, C.: A comprehensive performance evaluation of MM5-CMAQ for the summer 1999 southern oxidants study episode - Part III: diagnostic and mechanistic evaluations, Atmos. Environ., 40, 4856-4873, 2006.

Zakey, A. S., Giorgi, F., and Bi, X.: Modeling of sea salt in a regional climate model: fluxes and radiative forcing, J. Geophys. Res., 113, D14221, doi:10.1029/2007JD009209, 2008. 